\title{
Effect of dietary fat blend enriched in oleic or linoleic acid and monensin supplementation on dairy cattle performance, milk fatty acid profiles, and milk fat depression
}

\author{
M. He, ${ }^{\star 1}$ K. L. Perfield, $†$ H. B. Green, $\dagger$ and L. E. Armentano ${ }^{\star 2}$ \\ *Department of Dairy Science, University of Wisconsin, Madison 53706 \\ †Elanco Animal Health, 2500 Innovation Way, Greenfield, IN 46140
}

\section{ABSTRACT}

The effect of feeding increasing levels of oleic and linoleic acid both independently and together, with or without monensin, on milk fat depression was evaluated. Fifty-six Holstein cows were blocked by parity and then were divided by milk production into 2 groups (high or low) of 14 cows each within each parity block. A cow pair of 1 high and 1 low production cow within each parity block was fed in a single electronic feeding gate. Gates $(\mathrm{n}=28)$ were considered the experimental unit and were assigned to monensin $(17.5 \mathrm{~g} / \mathrm{t}$ of dry matter) or control as the main plot ( $\mathrm{n}=14$ each). The 7 cow pairs in each of the fixed effect groups were further assigned to a sequence of fat blend diets as split plot. Seven fat blend treatments in the split plot $7 \times 7$ Latin square were no added fat (no fat) and diets with increasing levels of oleic or linoleic acid: low C18:1 + low C18:2 (LOLL); low C18:1 + medium C18:2 (LOML); low C18:1 + high C18:2 (LOHL); medium C18:1 + low C18:2 (MOLL); medium C18:1 + medium C18:2 (MOML); and high C18:1 + low C18:2 (HOLL). Monensin feeding did not affect milk yield or concentration and yield of milk fat. Feeding monensin decreased the proportion of $\mathrm{C}<16$, increased the proportion of total $\mathrm{C} 18$, increased the proportion and yield of trans-10 C18:1, and increased the proportion of trans-10,cis-12 conjugated linoleic acid in milk fatty acids (FA). As dietary C18:1 or C18:2 increased beyond the concentration present in LOLL, milk fat concentration, milk fat yield, and proportion and yield of milk C $<16$ all decreased, and the proportion and yield of milk trans-10 C18:1 increased. A quadratic effect on milk fat concentration and yield was noticed for C18:2 feeding, but not for C18:1 feeding. When dietary contents of total FA and FA other than C18:1 and C18:2 were similar, C18:2-rich diets decreased milk fat concentration and yield compared with C18:1-rich diets (LOML

\footnotetext{
Received June 17, 2011.

Accepted October 30, 2011.

${ }^{1}$ Present address: BioZyme Inc., St. Joseph, MO 64504.

${ }^{2}$ Corresponding author: learment@facstaff.wisc.edu
}

vs. MOLL, and LOHL vs. HOLL), indicating that C18:2 is more potent than C18:1 for depressing milk fat. Increasing dietary FA content from no fat to LOLL, which increased primarily $\mathrm{C} 18: 1$ and $\mathrm{C} 18: 2$ with small increases in C18:0 and C16:0, decreased the secretion of $\mathrm{C}<16$ but increased total $\mathrm{C} 18$ secretion in milk. This suggests that biohydrogenation intermediates act to decrease mammary FA synthesis at low levels of added C18:1 and C18:2. No significant monensin $\times$ fat interactions were detected for the milk composition parameters analyzed; however, a monensin $\times$ fat interaction was found for milk fat trans-10 C18:1 proportion.

Key words: oleic, linoleic, monensin, milk fat depression

\section{INTRODUCTION}

Fatty acids occur in dairy rations due to intentional supplementation as a way to raise diet energy density or due to their inherent presence in certain feeds. However, milk fat depression (MFD) may occur when highly unsaturated oils are directly added to the diet, or when full-fat seeds or meal containing polyunsaturated FA are supplemented (Bauman and Griinari, 2001). Lipids undergo hydrolysis and biohydrogenation in the rumen, and unique FA intermediates that inhibit de novo FA synthesis in the mammary gland are produced under certain conditions (Bauman and Griinari, 2003). Experiments involving abomasal infusion of FA isomers have provided evidence that trans-10,cis-12 conjugated linoleic acid (CLA; Baumgard et al., 2002), trans9,cis-11 CLA (Perfield et al., 2007), cis-10,trans-12 CLA (Sæbø et al., 2005), and possibly trans-10 C18:1 (Shingfield et al., 2009) inhibit milk fat synthesis, although other unidentified FA may also contribute to MFD. Critical ingredients for this phenomenon are the profile and availability of unsaturated FA supplied to the rumen and ruminal conditions that favor incomplete or altered biohydrogenation pathways.

Milk fat depression has been found in several studies when a variety of lipid sources rich in linoleic acid (C18:2) were supplemented in the diet (Lock et al., 
2006; AlZahal et al., 2008; He and Armentano, 2011). Oleic acid (C18:1) is also common in many lipid sources, including canola oil, peanut oil, and high-oleic safflower oil. Contrary to C18:2, some studies suggest that dietary C18:1 intake does not inhibit milk fat synthesis. Selner and Schultz (1980) supplemented up to $500 \mathrm{~mL}$ of C18:1 per cow per day and found no significant change in milk fat concentration and yield. In another study, feeding $150 \mathrm{~mL}$ of C18:1 twice daily also had no significant effect on milk fat concentration (Shaw and Ensor, 1959). Jenkins (1998) and Rego et al. (2009) also fed C18:1-rich canola oil, which depressed milk fat synthesis and inhibited de novo FA synthesis, but the canola oil used in both studies contained greater than 10\% C18:2 of the total FA, which could contribute to MFD. However, AbuGhazaleh et al. (2005) confirmed the conversion of $\mathrm{C} 18: 1$ by mixed ruminal microbes to a multitude of trans-C18:1 isomers having double bond positions from C6 through C16. Trans-10 C18:1 is also potentially inhibitory to milk fat synthesis (Shingfield et al., 2009), and trans-6 to $8 \mathrm{C} 18: 1$ are negatively correlated with milk fat concentration (Kadegowda et al., 2008), although no evidence exists showing that these other monoene trans FA directly cause MFD. These facts suggest that both $\mathrm{C} 18: 1$ and $\mathrm{C} 18: 2$ may negatively affect milk fat synthesis concurrently.

A curvilinear relationship was reported between milk fat concentration and milk trans-10 C18:1 proportion or milk trans-10,cis-12 CLA proportion in milk FA, characterized by a steeper initial drop in milk fat (Bauman and Griinari, 2003). Lock et al. (2007) also found a similar curvilinear relationship between rumen outflow of trans-10 C18:1 (X,g/d) and milk fat concentration $(\mathrm{Y}, \%)\left(\mathrm{Y}=4.59 \mathrm{X}^{-0.14}\right)$. Because trans-10 $\mathrm{C} 18: 1$ and trans-10,cis-12 CLA are both FA intermediates from an altered pathway of C18:2 rumen biohydrogenation (Bauman and Griinari, 2003) and trans-10 C18:1 can also be synthesized from C18:1 under certain conditions (AbuGhazaleh et al., 2005), it is reasonable to believe that the MFD dose response to dietary C18:2 is nonlinear and more potent at lower C18:2 concentration. An objective of the current study was to evaluate the effects of level of dietary C18:1 and C18:2, independently and in combination, on milk production and composition of dairy cattle. A particular interest was the effects of these fats on milk FA production and composition.

Monensin was approved to be used in lactating dairy cattle for improving milk production efficiency by the US FDA in 2004 (Hamilton and Mitloehner, 2008). Monensin is a carboxylic polyether ionophore naturally produced by the bacterial strain Streptomyces cinnamonensis (Haney and Hoehn, 1967). Monensin functions as an ion antiporter that modifies monovalent cation transport across cell membranes of gram-positive bac- teria. Therefore, the ruminal bacteria population is altered and, as a consequence, monensin has numerous beneficial effects on dairy cattle, including less ruminal methane production (Odongo et al., 2007), improved milk production efficiency (Duffield et al., 2008a), decreased risk of ketosis and mastitis (Duffield et al., 2008b), and attenuated ruminal acidosis in cattle fed a high-concentrate diet (Bergen and Bates, 1984).

However, similar to unsaturated oils, monensin has also been associated with MFD by inhibiting unsaturated FA biohydrogenation within the rumen, as evidenced by altered milk FA composition (Sauer et al., 1998). A decrease in milk fat concentration (Phipps et al., 2000; Benchaar et al., 2006) or a decrease of both milk fat concentration and yield (Broderick, 2004; AlZahal et al., 2008) was observed when monensin was fed to lactating dairy cattle. Feeding monensin resulted in a more significant decrease in milk fat concentration when a greater amount of C18:2-rich soybean oil was present in the diet, which suggested possible monensin $\times$ soybean oil interaction (AlZahal et al., 2008). Their study also found greater milk fat proportion of total trans-18:1, including trans- 6 to 8 and trans-10 C18:1 and a greater proportion of total CLA isomers including milk fat-depressing trans-9,cis-11 and trans10,cis-12 CLA with monensin feeding when soybean oil was present (AlZahal et al., 2008).

A recent meta-analysis also indicated a possible enhanced effect of monensin on decreasing milk fat yield with increased dietary C18:1 intake (Duffield et al., 2008a). Thus, the effect of feeding vegetable oils rich in unsaturated FA, especially $\mathrm{C} 18: 1$ and $\mathrm{C} 18: 2$, on MFD may be amplified by monensin feeding, and the second objective of this study was to evaluate possible interactions between dietary C18:1 or C18:2 level and monensin supplementation on dairy cattle performance, especially milk fat synthesis.

\section{MATERIALS AND METHODS}

\section{Animals and Treatments}

The basic design of this trial was to test the monensin effect in continuous design, with 28 cows receiving monensin throughout the trial and 28 control cows. Within these treatment groups, a Latin square design was used to apply the fat blend treatments so that each animal received each of the 7 fat blend treatments but only 1 monensin level. This design was more statistically powerful to test the fat blend effects but gave less power for the effect of monensin. However, possibility still exists that results in this study could be influenced by accretion and remobilization of body fat from period to period. Fifty-six lactating Holstein cows 
were divided by parity into 2 blocks 28 primiparous (PRI), 42 to 147 DIM; and 28 multiparous (MUL), 55 to $142 \mathrm{DIM}$ ] on d 1 of the adaptation period. Cows were housed in a freestall barn equipped with 32 Insentec electronic feeding gates (RIC system; Insentec BV, Marknesse, the Netherlands), as described by Chapinal et al. (2007). Within each parity block, cows were divided by their projected 305-d milk production (DairyComp 305; Valley Agricultural Software, Tulare, CA) into 2 groups (high or low) of 14 cows each. A cow pair of 1 high-production cow and 1 low-production cow within each parity block was randomly selected as an experimental unit and assigned to a feeding gate $(28$ cow pairs in total assigned to 28 of the 32 gates, 14 in each parity block). During a 2 -wk covariate period, all cows were fed the same herd TMR, which already had $12.95 \mathrm{~g}$ of monensin/t of DM. The covariate diet contained $13.8 \%$ corn silage, $25.7 \%$ alfalfa haylage, $8.3 \%$ alfalfa hay, $1.8 \%$ wheat straw, $50.4 \%$ concentrate mix, $18.2 \% \mathrm{CP}$, and $31.3 \% \mathrm{NDF}$ on a DM basis. After the covariate period, the concentration of monensin in the TMR was increased to $17.5 \mathrm{~g} / \mathrm{t}$ of DM according to the recommendation of Elanco Animal Health (Greenfield, IN), and a 3 -wk adaptation period was applied in which monensin (0 or $17.5 \mathrm{~g} / \mathrm{t}$ of DM, $\mathbf{M}-$ or $\mathbf{M}+$ ) in an experimental diet (no fat blend supplementation, no fat) was randomly assigned to 7 cow pairs per parity block, resulting in a main plot randomized block design with 1 degree of freedom for parity block, 1 degree of freedom for monensin, 1 degree of freedom for monensin by parity interaction, and 24 degrees of freedom for error. Monensin feeding status was maintained throughout the adaptation period and the following 7 periods. These 4 groups of 7 cow pairs (PRI/M-, PRI/M+, MUL/ $\mathrm{M}-$, and MUL/M+) were then each fed a sequence of 7 diets with different fat blends in a $7 \times 7$ Latin square design with 3 -wk periods applied as a split plot after the monensin adaptation period. The first $17 \mathrm{~d}$ of each period were for diet adaptation, with the last $4 \mathrm{~d}$ used for sample collection.

Dietary treatments were a $2 \times 7$ factorial arrangement of 0 or $17.5 \mathrm{~g}$ of monensin/t and 7 different oil treatments (14 diets in total). Oil treatments were 1) no added fat $(0.36 \% \mathrm{C} 18: 1+0.89 \% \mathrm{C} 18: 2$ in diet DM, no fat), or different fat blends with increasing levels of oleic or linoleic acid: 2) low oleic + low linoleic supplementation (0.98\% C18:1 + 1.51\% C18:2, LOLL); 3) low oleic + medium linoleic $(1.01 \%$ C18:1 $+2.69 \%$ C18:2, LOML); 4) low oleic + high linoleic $(1.04 \%$ C18:1 + $3.86 \%$ C18:2, LOHL); 5) medium oleic + low linoleic $(2.14 \%$ C18:1 + 1.52\% C18:2, MOLL); 6) medium oleic + medium linoleic $(2.18 \% \mathrm{C} 18: 1+2.69 \% \mathrm{C} 18: 2$, MOML); and 7) high oleic + low linoleic (3.32\% C18:1 $+1.52 \%$ C18:2, HOLL; Figure 1; Table 1). Increments of C18:1 and C18:2 were equal so that diets LOML and MOLL were equal to each other in total and added fat, and diets HOLL, LOHL, and MOML were also equal in fat with each other. Lipid sources (Table 2) used to mix fat blends were palm oil (PO; Columbus Foods Co., Des Plaines, IL), tallow (Max-Fat Corp., Green Bay, WI), high-oleic safflower oil (Columbus Foods Co.), and high-linoleic safflower oil (Alnor Oil Co., Valley Stream, NY), replacing the same amount of corn starch used in the no fat treatment. The sequence of fat blend treatments was selected to balance for 1-period carryover effects. Carryover effects extending beyond 1 period were not accounted for in this design.

Animal use procedures were approved by the Animal Care and Use Committee for the College of Agricultural and Life Sciences at the University of Wisconsin-Madison. Cows were milked twice daily at 0330 and 1530 $\mathrm{h}$, and milk weights were recorded at each milking. No animals received bovine somatotropin (Posilac; Elanco Animal Health) during the trial period. Cows had free access to water and were fed a TMR twice daily at the beginning of the trial. Feeding frequency was increased to 3 times daily during period 2 to prevent overfilling of the feeding bins and thereby minimize cows stealing feed from non-assigned gates by reaching over the closed gate. Incorrect feed consumed in this manner is recorded and assigned to the appropriate cow's intake by the feeding system. Corn silage, alfalfa haylage, concentrate mix, and respective fat blends were mixed once daily before morning feeding and offered ad libitum on an as-fed basis. Cows had access to feed-

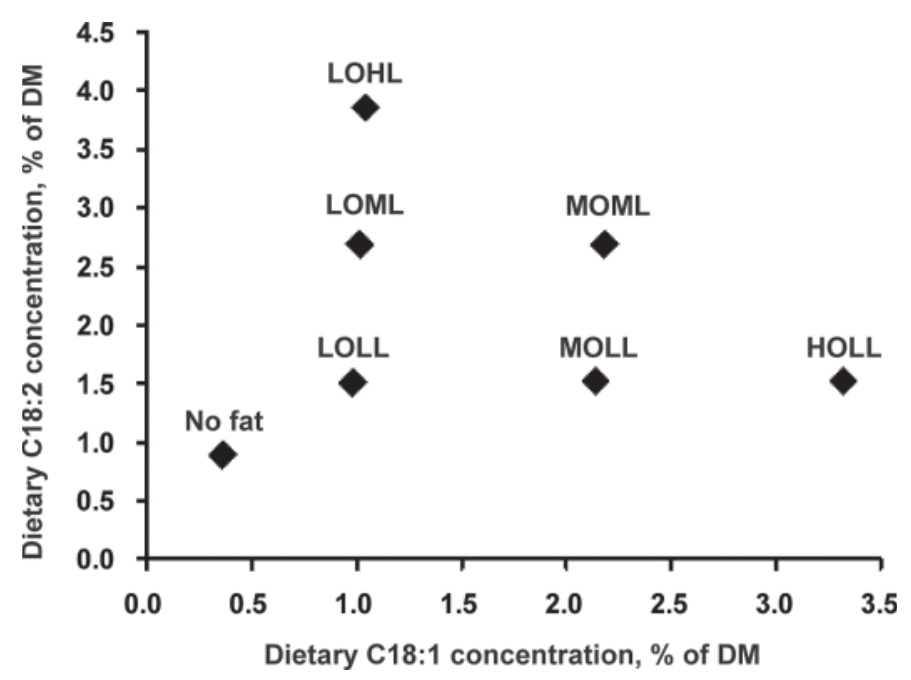

Figure 1. Dietary C18:1 and C18:2 concentrations of 7 experimental diets. No fat: no added fat; LOLL: low C18:1, low C18:2; LOML: low C18:1, medium C18:2; LOHL: low C18:1, high C18:2; MOLL: medium C18:1, low C18:2; MOML: medium C18:1, medium C18:2; HOLL: high C18:1, low C18:2. 
Table 1. Fatty acid composition of experimental diets

\begin{tabular}{lccccccc}
\hline & \multicolumn{7}{c}{ Treatment $^{1}$} \\
\cline { 2 - 8 } $\begin{array}{l}\text { Fatty acid, } \\
\text { g/100 g of DM }\end{array}$ & No fat & LOLL & LOML & LOHL & MOLL & MOML & HOLL \\
\hline C14:0 & 0.01 & 0.02 & 0.02 & 0.01 & 0.02 & 0.02 & 0.02 \\
C16:0 & 0.38 & 0.63 & 0.63 & 0.62 & 0.63 & 0.63 & 0.64 \\
C18:0 & 0.05 & 0.15 & 0.15 & 0.15 & 0.15 & 0.16 & 0.16 \\
C18:1, total & 0.36 & 0.98 & 1.01 & 1.04 & 2.14 & 2.18 & 3.32 \\
C18:2, n-6 & 0.89 & 1.51 & 2.69 & 3.86 & 1.52 & 2.69 & 1.52 \\
C18:3, n-3 & 0.36 & 0.37 & 0.39 & 0.41 & 0.37 & 0.39 & 0.36 \\
Other & 0.39 & 0.46 & 0.43 & 0.42 & 0.45 & 0.42 & 0.44 \\
Total & 2.44 & 4.12 & 5.32 & 6.51 & 5.28 & 6.49 & 6.46
\end{tabular}

${ }^{1}$ No fat: without fat blend; LOLL: low C18:1, low C18:2; LOML: low C18:1, medium C18:2; LOHL: low C18:1, high C18:2; MOLL: medium C18:1, low C18:2; MOML: medium C18:1, medium C18:2; HOLL: high C18:1, low C18:2.

ers approximately $20 \mathrm{~h}$ daily. To maintain a constant proportion of feed ingredients on a $\mathrm{DM}$ basis, $60^{\circ} \mathrm{C} \mathrm{DM}$ of forages was determined weekly and as-fed ration composition was adjusted accordingly. Diet without fat blend supplementation (no fat) consisted of $17.6 \%$ corn silage, $34.8 \%$ alfalfa silage, and $47.6 \%$ concentrate mix on a DM basis (Table 3). During the last week of the fifth period, the diets were found to be low in sodium (0.17 to $0.18 \%$; Table 3 ) compared with the NRC requirement $(0.22 \%)$ based on cows at 80 DIM, weighing $680 \mathrm{~kg}$, producing $40 \mathrm{~kg}$ of milk daily with $3.5 \%$ milk fat and 3.0\% milk true protein, and a target DMI of $25.0 \mathrm{~kg} / \mathrm{d}$. From d 20 of period 5, $0.24 \%$ additional salt was supplemented and replaced the same amount of grain mix in TMR. The adjusted diet met all of the NRC nutrient requirements based on the above cow conditions.

\section{Sampling and Analysis}

The amount of feeds consumed by individual cows was recorded daily by the RIC electronic feeding system and values for the last $4 \mathrm{~d}$ of each period were used to calculate animal DMI, assuming the DM of the feed consumed was equal to the DM of feed offered. Corn silage, alfalfa haylage, and concentrate mix were sampled weekly. Samples were composited by period and dried at $60^{\circ} \mathrm{C}$ for $48 \mathrm{~h}$. Feed samples were then ground through a 1-mm screen (Wiley Mill; Arthur H. Thomas Co., Philadelphia, PA), and analyses for DM, ash, NDF, ADF, CP, ether extract, starch, and mineral content were performed according to the procedures described previously (He and Armentano, 2011). Feed FA profile was determined following the procedure of Sukhija and Palmquist (1988). The percent total FA was calculated by adding each FA from C12:0 to C22:0, with C17:0 used as an internal standard, except tallow was analyzed using C19:0 as internal standard. Diet chemical composition was calculated based on analysis of forages, concentrate mix, starch, and oils and feed proportions used.

All measurements were made on individual animals. Animal BW and BCS were measured once during the last week of each period, except for the covariate period in which BW and BCS were measured on d 6 of the covariate period. Milk production was recorded daily and milk samples for milk components analysis were collected at the p.m. milking on d 2, 5, and 11 of each period and at both a.m. and p.m. milkings on the last $4 \mathrm{~d}$ of each period. Milk samples from p.m. sampling on $\mathrm{d} 2,5,11,18,19,20$, and 21 of each period were used to evaluate how fast cows adapted to new treatment diets. Concentrations of fat, true protein, lactose, non-fat solid, MUN, and SCC in individual a.m. and

Table 2. Major fatty acid composition of vegetable oils/fats used to mix fat blends

\begin{tabular}{lrrrr}
\hline & \multicolumn{4}{c}{ Vegetable oil/fat $^{1}$} \\
\cline { 2 - 5 } Fatty acid, $\%$ & Tallow & PO & OSAF & LSAF \\
\hline of total FA & 25.0 & 37.2 & 5.0 & 6.0 \\
C18:0 & 19.2 & 4.0 & 2.0 & 2.6 \\
C18: 1 & 41.7 & 41.4 & 78.6 & 16.7 \\
C18:2 & 2.2 & 14.8 & 13.4 & 73.0 \\
C18:3 & 0.2 & 0.4 & 0.0 & 1.2 \\
Other & 11.7 & 2.2 & 1.0 & 0.5 \\
\hline
\end{tabular}

${ }^{1}$ PO: palm oil; OSAF: high-oleic safflower oil; LSAF: high-linoleic safflower oil. 
Table 3. Ingredients and chemical composition of experimental diets ${ }^{1}$

\begin{tabular}{|c|c|c|c|c|c|c|c|}
\hline Item & \multicolumn{7}{|c|}{ Treatment $^{2}$} \\
\hline \multicolumn{8}{|l|}{ Ingredient, $\mathrm{g} / 100 \mathrm{~g}$ of $\mathrm{DM}$} \\
\hline Corn silage $^{4}$ & 17.6 & 17.6 & 17.6 & 17.6 & 17.6 & 17.6 & 17.6 \\
\hline Grain mix $^{5}$ & 43.5 & 43.5 & 43.5 & 43.5 & 43.5 & 43.5 & 43.5 \\
\hline Corn starch & 4.1 & 2.4 & 1.2 & 0.0 & 1.2 & 0.0 & 0.0 \\
\hline High-linoleic safflower oil & 0.0 & 0.7 & 2.4 & 4.1 & 0.5 & 2.1 & 0.2 \\
\hline \multicolumn{8}{|l|}{ Chemical composition } \\
\hline $\mathrm{NE}_{\mathrm{L}}{ }^{6}{ }^{6} \mathrm{Mcal} / \mathrm{kg}$ & 1.59 & 1.63 & 1.69 & 1.74 & 1.68 & 1.73 & 1.73 \\
\hline $\mathrm{CP}, \%$ & 17.0 & 17.0 & 17.0 & 17.0 & 17.0 & 17.0 & 17.0 \\
\hline NDF, $\%$ & 29.3 & 29.3 & 29.3 & 29.3 & 29.3 & 29.3 & 29.3 \\
\hline $\mathrm{ADF}, \%$ & 21.4 & 21.4 & 21.4 & 21.4 & 21.4 & 21.4 & 21.4 \\
\hline $\mathrm{Na}, \%$ & 0.18 & 0.17 & 0.17 & 0.17 & 0.17 & 0.17 & 0.17 \\
\hline
\end{tabular}

${ }^{1}$ The chemical compositions of the experimental diets are calculated from the analyses of individual feed ingredients as described in the section Sampling and Analysis.

${ }^{2}$ No fat: without fat blend; LOLL: low C18:1, low C18:2; LOML: low C18:1, medium C18:2; LOHL: low C18:1, high C18:2; MOLL: medium C18:1, low C18:2; MOML: medium C18:1, medium C18:2; HOLL: high C18:1, low C18:2.

${ }^{3}$ Alfalfa haylage: $38.2 \%$ NDF, $22.1 \%$ CP, $10.1 \%$ ash, and $4.1 \%$ ether extract (DM basis).

${ }^{4}$ Corn silage: $38.7 \%$ NDF, $6.9 \%$ CP, $3.5 \%$ ash, and $3.8 \%$ ether extract (DM basis).

${ }^{5}$ Grain mix of total diet: $10.5 \%$ dry ground shelled corn; $8.0 \%$ dried beet pulp; $6.0 \%$ corn starch; $5.7 \%$ soybean meal (48\% CP); $5.7 \%$ soybean hulls; $3.7 \%$ corn gluten feed; $1.8 \%$ corn gluten meal; $0.9 \%$ blood meal; 0.1\% Essential M [methionine supplement, purchased from Vita Plus Corp. (Madison, WI) and contains 60\% Adisseo MetaSmart Liquid and 40\% carrier]; $1.2 \%$ mineral and vitamin supplement. Monensin was carried in the grain mix to provide a $17.5 \mathrm{~g} / \mathrm{t}$ of TMR DM. The concentration of monensin in the grain mix was $40.3 \mathrm{~g} / \mathrm{t}$ of grain DM.

${ }^{6}$ Predicted by NRC (2001).

${ }^{7}$ Ether extract contents of 4 fat/oils were not analyzed. Assumed fat/oils have 99.9\% ether extract (NRC, 2001).

p.m. samples were determined by infrared analysis using a Foss MilkoScan FT6000 (AgSource Laboratories, Menomonie, WI). A second set of a.m. and p.m. milk samples were collected on d 20 of each period for milk FA analysis. Detailed procedures of milk fat collection, lipid extraction, FA methylation, and FA GC analysis were described previously (He and Armentano, 2011).

\section{Statistical Analysis}

Data were analyzed using the MIXED procedure of SAS (Version 9.1; SAS Institute Inc., Cary, NC). To improve the accuracy of the model, milk yield, milk components concentration and yield, DMI, BW, and BCS during the covariate period were used as covariates for analysis of the same variable during the experimental periods. Variables except for milk FA yield and proportion were analyzed using the following model:

$$
\begin{gathered}
\mathrm{Y}=\mu+\text { covariate }+\mathrm{M}+\mathrm{Par}+(\mathrm{M} \times \text { Par })+\mathrm{G} \\
+\mathrm{O}+(\mathrm{M} \times \mathrm{O})+(\mathrm{Par} \times \mathrm{O})+\mathrm{Per}+(\mathrm{Per} \times \mathrm{M}) \\
+(\text { Per } \times \text { Par })+\mathrm{g}+\mathrm{Prod}+\mathrm{e},
\end{gathered}
$$

where $\mathrm{Y}$ is the response variable; $\mu$ is the overall mean; $M$ is the fixed effect of monensin; Par is the fixed effect of animal parity; $\mathrm{G}$ is the random effect of gate within $(\mathrm{M} \times \mathrm{Par})$ main-plot; $\mathrm{O}$ is the fixed effect of fat blend treatments; Per is the fixed effect of period; $g$ is the random effect of gate within $(\mathrm{M} \times \mathrm{Par} \times \mathrm{O} \times \mathrm{Per})$ subplot; Prod is the fixed effect of production; and e is the random residual error.

Individual milk FA yield and proportion were analyzed using the model without covariate:

$$
\begin{gathered}
\mathrm{Y}=\mu+\mathrm{M}+\mathrm{Par}+(\mathrm{M} \times \mathrm{Par})+\mathrm{G}+\mathrm{O} \\
+(\mathrm{M} \times \mathrm{O})+(\text { Par } \times \mathrm{O})+\text { Per }+(\mathrm{Per} \times \mathrm{M}) \\
+(\text { Per } \times \text { Par })+\mathrm{g}+\text { Prod }+\mathrm{e} .
\end{gathered}
$$

Preplanned contrast statements were included to test the linear and quadratic effects of C18:1; the linear and quadratic effects of $\mathrm{C} 18: 2$; the interaction of $\mathrm{C} 18: 1 \times$ C18:2; and no fat versus LOLL within fat blend main effect. Preplanned contrasts were also used to determine monensin $\times$ fat treatment interactions for the same 
treatment comparisons; $\mathrm{G}$ served as the error term for monensin, parity, and monensin $\times$ parity interaction; $\mathrm{g}$ served as the error term for fat blend effect and monensin $\times$ fat blend interactions unless PROC MIXED in SAS defaulted to the residual error. Reported values were least squares means with significance declared at $P<0.05$.

\section{RESULTS AND DISCUSSION}

\section{Intakes, Milk Production, and Milk Composition}

Several studies have involved increasing levels of supplementation of vegetable oils on dairy cattle performance. However, the linear or quadratic effect of specific FA may be confounded by other contaminating FA because supplementing more oils results in the increase of more than $1 \mathrm{FA}$ in the diet. In the current study, dietary levels of C18:1 or C18:2 were increased separately in the 6 oil-added diets while keeping other dietary FA constant. Thus, the effect of C18:1 or C18:2 on animal performance can be clearly distinguished from each other, except when comparing no fat to LOLL.

Five cows were removed from the trial pen because they were stealing feed from open gates ( 3 in $M+, 2$ in $\mathrm{M}-$ ). In this feeding system, when cows steal from open gates, the feed they consume is not only likely the incorrect diet but also the intake is mistakenly attributed to the displaced cow rather than to the stealer. Cows may also consume incorrect feed from bins with closed gates by reaching over the closed gate. In this latter case, intake is associated with the correct cow and cows can be left in the experimental pen, although these cows are not receiving only their assigned diet. Data for 36 cow period cells (out of a total of 392 cells) were removed from the data set because cows ate more than $5 \%$ of their total as-fed intake from closed gates containing diets they were not assigned during the last 2 wk of the period.

In the current study, feeding any of the 6 fat blend diets up to $4.07 \%$ supplemental FA had no negative effect on DMI and milk yield when compared with the no-fat diet (Table 4). This is in agreement with previous research in which DMI was not affected when cows were fed $5 \%$ high-oleic or high-linoleic safflower oil (He and Armentano, 2011), or 5\% sunflower oil (Loor et al., 2005). Our results showed that feeding increasing levels of dietary C18:1 from $0.98 \%$ up to $3.32 \%$ had no significant effect on DMI. However, DMI was linearly decreased as C18:2 in the diet increased from 1.51 to $3.86 \%$. Dhiman et al. (2000) reported no effect on DMI when soybean oil was supplemented up to $4 \%(3.28 \%$ dietary C18:2).
Although feeding fat blend diets did not affect milk yield when compared with the no-fat diet, the addition of either C18:1 or C18:2 to LOLL linearly decreased milk yield (Table 4). AlZahal et al. (2008) reported a positive linear effect of soybean oil feeding $(0,1.7$, and $3.4 \%$ ) on milk yield, which is inconsistent with the results in our present study. Decreased milk fat yield and concentration were found when dietary C18:1 and C18:2 were supplemented at increasing levels independently in the current study (Table 4). This result supports AlZahal et al. (2008) who reported a linear decrease in milk fat yield and concentration by increasing soybean oil supplementation. Milk fat yield and concentration decreased significantly when C18:1 or C18:2 was supplemented from low to medium level (LOLL vs. MOLL and LOLL vs. LOML, respectively), but not significantly from medium to high level (MOLL vs. HOLL and LOML vs. LOHL, respectively). However, a significant quadratic effect on milk fat yield and concentration was only noticed for C18:2 feeding (Table 4 and Figure 2). AlZahal et al. (2008) only reported a linear effect of feeding increasing levels of soybean oil $(0,1.7$, and $3.4 \%)$ on milk fat yield and concentration. This is probably because fat blend treatments used in the current study covered a wider range of dietary C18:2 content (high C18:2 diet LOHL provided 3.9\% dietary C18:2). The $3.4 \%$ soybean oil diet in the study of AlZahal et al. (2008) only provided $2.2 \%$ dietary C18:2, which was lower than 2.7\% C18:2 of our LOML diet. Another explanation for the quadratic effect of C18:2 could be that increased levels of soybean oil fed are confounded by concomitant change of other FA in soybean oil. When an equal-fat comparison was made, animal milk fat yield and concentration were significantly reduced when fed the C18:2-rich diet compared with the C18:1-rich diet (LOML vs. MOLL, and LOHL vs. HOLL; Table 4 and Figure 2), suggesting that C18:2 is more potent than C18:1 at causing MFD. However, differences in milk fat yield and concentration were not found in cows fed diets with either $3.7 \%$ high-oleic or high-linoleic sunflower oil (Kalscheur et al., 1997). In the current study, an oleic $\times$ linoleic acid interaction was found to affect milk fat concentration such that when dietary C18:1 was at a low level, increasing dietary C18:2 from a low to medium level decreased milk fat concentration by $0.63 \%$ (LOML vs. LOLL; Table 4). However, milk fat concentration was only decreased by $0.42 \%$ by increasing dietary C18:2 when C18:1 was at a medium level (MOML vs. MOLL).

Both C18:1 and C18:2 linearly increased milk protein concentration with no change in protein yield in this study (Table 4). Some previous research (Leonardi et al., 2005; Abdelqader et al., 2009) reported unaffected milk protein yield by oil supplementation, which is con- 
Table 4. Effect of fat blend and monensin (Mon) supplementation on intake, milk production, and milk composition

\begin{tabular}{|c|c|c|c|c|c|c|c|c|c|c|c|c|c|c|c|c|c|c|c|c|}
\hline \multirow[b]{2}{*}{ Item } & \multicolumn{7}{|c|}{ Fat blend treatment ${ }^{1}$} & \multicolumn{4}{|c|}{ Monensin } & \multicolumn{9}{|c|}{$P$-value ${ }^{3}$} \\
\hline & $\begin{array}{l}\text { No } \\
\text { fat }\end{array}$ & LOLL & LOML & LOHL & MOLL & MOML & HOLL & $\mathrm{SEM}^{2}$ & Mon- & Mon+ & SEM & $\begin{array}{l}\text { C18:1, } \\
\quad \mathrm{L}\end{array}$ & $\begin{array}{l}\text { C18:1, } \\
\text { Q }\end{array}$ & $\begin{array}{l}\mathrm{C} 18: 2, \\
\quad \mathrm{~L}\end{array}$ & $\begin{array}{l}\mathrm{C} 18: 2, \\
\mathrm{Q}\end{array}$ & $\begin{array}{c}\mathrm{C} 18: 1 \\
\times \mathrm{C} 18: 2\end{array}$ & $\begin{array}{l}\text { No fat } \\
\text { vs. } \\
\text { LOLL }\end{array}$ & Mon & $\begin{array}{l}\text { Mon } \\
\times \text { oil }\end{array}$ & $\begin{array}{l}\text { Mon } \\
\times \text { par }\end{array}$ \\
\hline $\mathrm{BW}, \mathrm{kg}$ & 699.4 & 699.2 & 699.0 & 700.1 & 699.0 & 699.0 & 701.1 & 5.9 & 698.5 & 700.6 & 6.7 & 0.71 & 0.79 & 0.87 & 0.88 & 0.98 & 0.98 & 0.82 & 0.83 & 0.82 \\
\hline BCS & $3.46^{\mathrm{ab}}$ & $3.40^{\mathrm{ab}}$ & $3.47^{\mathrm{ab}}$ & $3.47^{\mathrm{ab}}$ & $3.43^{\mathrm{ab}}$ & $3.55^{\mathrm{a}}$ & $3.35^{\mathrm{b}}$ & 0.06 & 3.44 & 3.46 & 0.05 & 0.33 & 0.24 & 0.23 & 0.55 & 0.53 & 0.34 & 0.84 & 0.52 & 0.53 \\
\hline DMI, $\mathrm{kg} / \mathrm{d}$ & $23.8^{\mathrm{ab}}$ & $24.1^{\mathrm{a}}$ & $23.3^{\mathrm{ab}}$ & $22.6^{\mathrm{b}}$ & $23.9^{\mathrm{ab}}$ & $23.5^{\mathrm{ab}}$ & $23.5^{\mathrm{ab}}$ & 0.5 & 23.4 & 23.7 & 0.5 & 0.18 & 0.87 & $<0.01$ & 0.96 & 0.55 & 0.52 & 0.73 & 0.90 & 0.80 \\
\hline \multicolumn{21}{|l|}{$\begin{array}{l}\text { Production, } \\
\mathrm{kg} / \mathrm{d}\end{array}$} \\
\hline Milk & $33.7^{\mathrm{abc}}$ & $35.8^{\mathrm{a}}$ & $34.0^{\mathrm{ab}}$ & $30.6^{\mathrm{c}}$ & $35.2^{\mathrm{ab}}$ & $32.5^{\mathrm{bc}}$ & $33.6^{\mathrm{abc}}$ & 1.4 & 33.3 & 34.0 & 1.7 & 0.03 & 0.55 & $<0.01$ & 0.38 & 0.56 & 0.05 & 0.76 & 0.32 & 0.75 \\
\hline $\mathrm{ECM}^{4}$ & $33.6^{\mathrm{a}}$ & $33.8^{\mathrm{a}}$ & $29.2^{\mathrm{bc}}$ & $26.5^{\mathrm{d}}$ & $31.6^{\mathrm{ab}}$ & $28.1^{\mathrm{cd}}$ & $29.9^{\mathrm{bc}}$ & 1.2 & 30.7 & 30.1 & 1.4 & $<0.01$ & 0.78 & $<0.01$ & 0.24 & 0.41 & 0.82 & 0.77 & 0.51 & 0.93 \\
\hline Fat & $1.17^{\mathrm{a}}$ & $1.13^{\mathrm{a}}$ & $0.84^{\mathrm{cd}}$ & $0.74^{\mathrm{d}}$ & $0.98^{\mathrm{b}}$ & $0.79^{\mathrm{d}}$ & $0.91^{\mathrm{bc}}$ & 0.04 & 0.97 & 0.90 & 0.05 & $<0.01$ & 0.28 & $<0.01$ & $<0.01$ & 0.08 & 0.21 & 0.32 & 0.70 & 0.73 \\
\hline Protein & 1.09 & 1.12 & 1.11 & 1.06 & 1.11 & 1.10 & 1.08 & 0.04 & 1.09 & 1.10 & 0.04 & 0.17 & 0.72 & 0.04 & 0.41 & 0.96 & 0.30 & 0.78 & 0.86 & 0.61 \\
\hline Lactose & $1.63^{\mathrm{ab}}$ & $1.75^{\mathrm{a}}$ & $1.62^{\mathrm{ab}}$ & $1.45^{\mathrm{c}}$ & $1.71^{\mathrm{ab}}$ & $1.56^{\mathrm{bc}}$ & $1.62^{\mathrm{ab}}$ & 0.07 & 1.60 & 1.64 & 0.08 & 0.01 & 0.57 & $<0.01$ & 0.59 & 0.74 & 0.04 & 0.73 & 0.36 & 0.74 \\
\hline SNF & $3.03^{\mathrm{ab}}$ & $3.20^{\mathrm{a}}$ & $3.05^{\mathrm{ab}}$ & $2.81^{\mathrm{b}}$ & $3.15^{\mathrm{a}}$ & $2.97^{\mathrm{ab}}$ & $3.02^{\mathrm{ab}}$ & 0.12 & 3.00 & 3.06 & 0.14 & 0.04 & 0.60 & $<0.01$ & 0.49 & 0.78 & 0.07 & 0.75 & 0.50 & 0.68 \\
\hline \multicolumn{21}{|c|}{ Composition, } \\
\hline Fat & $3.50^{\mathrm{a}}$ & $3.17^{\mathrm{b}}$ & $2.54^{\mathrm{de}}$ & $2.47^{\mathrm{e}}$ & $2.88^{\mathrm{c}}$ & $2.46^{\mathrm{e}}$ & $2.76^{\mathrm{cd}}$ & 0.08 & 2.94 & 2.71 & 0.09 & $<0.01$ & 0.19 & $<0.01$ & $<0.01$ & 0.04 & $<0.01$ & 0.08 & 0.95 & 0.39 \\
\hline Protein & $3.23^{\mathrm{cd}}$ & $3.17^{\mathrm{d}}$ & $3.32^{\mathrm{bc}}$ & $3.57^{\mathrm{a}}$ & $3.21^{\mathrm{cd}}$ & $3.44^{\mathrm{ab}}$ & $3.27^{\mathrm{cd}}$ & 0.05 & 3.31 & 3.33 & 0.06 & 0.03 & 0.81 & $<0.01$ & 0.23 & 0.23 & 0.20 & 0.79 & 0.12 & 0.84 \\
\hline Lactose & $4.86^{\mathrm{a}}$ & $4.86^{\mathrm{a}}$ & $4.77^{\mathrm{ab}}$ & $4.70^{\mathrm{b}}$ & $4.82^{\mathrm{a}}$ & $4.80^{\mathrm{ab}}$ & $4.80^{\mathrm{ab}}$ & 0.04 & $\begin{array}{l}5.01 \\
4.79\end{array}$ & 4.81 & $\begin{array}{l}0.00 \\
0.04\end{array}$ & 0.08 & $\begin{array}{l}0.71 \\
0.71\end{array}$ & $<0.01$ & 0.77 & 0.17 & 0.89 & 0.79 & 0.89 & $\begin{array}{l}0.04 \\
0.52\end{array}$ \\
\hline SNF & $9.00^{\mathrm{c}}$ & $8.95^{\mathrm{c}}$ & $9.04^{\mathrm{bc}}$ & $9.25^{\mathrm{a}}$ & $8.97^{\mathrm{c}}$ & $9.20^{\mathrm{ab}}$ & $9.02^{\mathrm{c}}$ & 0.06 & 9.04 & 9.08 & 0.07 & 0.18 & 0.75 & $<0.01$ & 0.22 & 0.08 & 0.40 & 0.67 & 0.50 & 0.86 \\
\hline $\begin{array}{l}\mathrm{SCC}, \\
\log _{10} / \mathrm{mL}\end{array}$ & $4.82^{\mathrm{cd}}$ & $4.80^{\mathrm{d}}$ & $4.97^{\mathrm{abc}}$ & $5.13^{\mathrm{a}}$ & $4.86^{\mathrm{bcd}}$ & $5.00^{\mathrm{ab}}$ & $4.90^{\mathrm{bcd}}$ & 0.06 & 4.91 & 4.94 & 0.06 & 0.04 & 0.82 & $<0.01$ & 0.83 & 0.64 & 0.67 & 0.77 & 0.45 & 0.86 \\
\hline $\begin{array}{l}\text { MUN, } \\
\mathrm{mg} / \mathrm{dL}\end{array}$ & $13.1^{\mathrm{a}}$ & $11.4^{\mathrm{b}}$ & $9.6^{\mathrm{c}}$ & $8.2^{\mathrm{d}}$ & $10.5^{\mathrm{bc}}$ & $9.5^{\mathrm{c}}$ & $11.0^{\mathrm{b}}$ & 0.3 & 10.5 & 10.5 & 0.3 & 0.22 & 0.01 & $<0.01$ & 0.51 & 0.07 & $<0.01$ & 0.98 & 0.42 & 0.18 \\
\hline
\end{tabular}

№ fat: without fat blend; LOLL: low C18:1, low C18:2; LOML: low C18:1, medium C18:2; LOHL: low C18:1, high C18:2; MOLL: medium C18:1, low C18:2; MOML: medium C18:1, medium C18:2; HOLL: high C18:1, low C18:2.

을 $\quad{ }^{2}$ Standard error of the means for calculated statistical responses.

D. L: linear effect; Q: quadratic effect; par: parity.

疍- $\quad{ }^{4}$ Energy-corrected milk, calculated from milk energy output using the equation: $\mathrm{NE}_{\mathrm{L}}, \mathrm{Mcal} / \mathrm{d}=$ milk yield, $\mathrm{kg} / \mathrm{d} \times(0.0929 \times$ percent fat $+0.0563 \times$ percent true protein +0.0395

ก $\times$ percent lactose) (Tyrrell and Reid, 1965), divided by 0.7 Mcal of $\mathrm{NE}_{\mathrm{L}} / \mathrm{kg}$ of milk. 


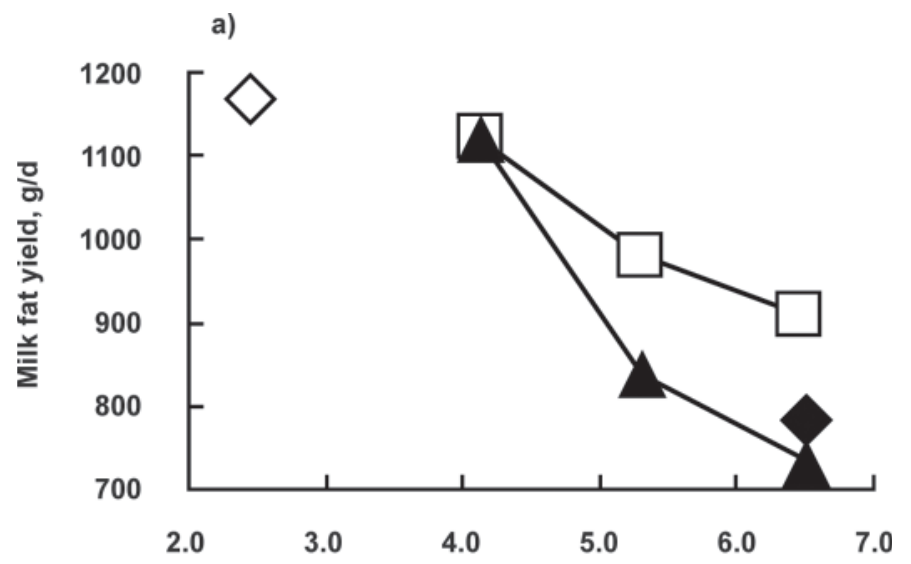

b)

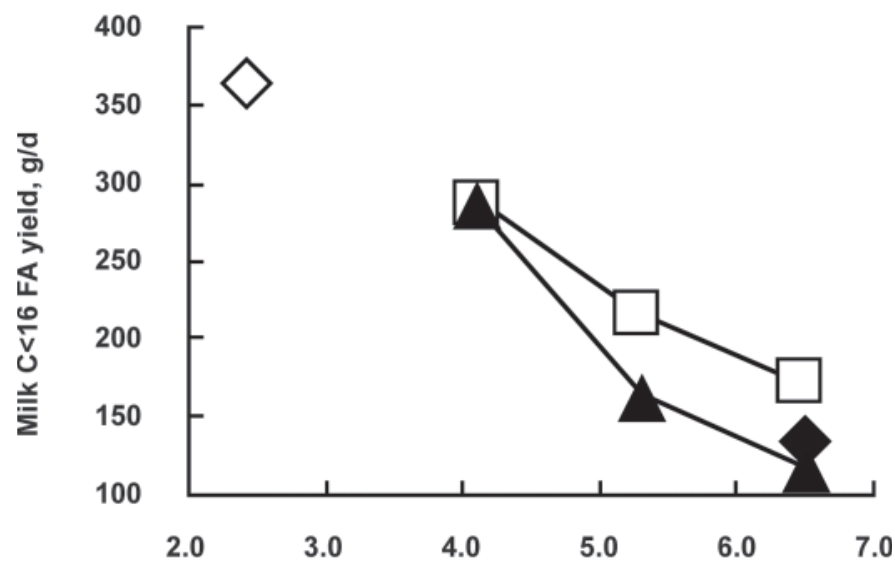

c)

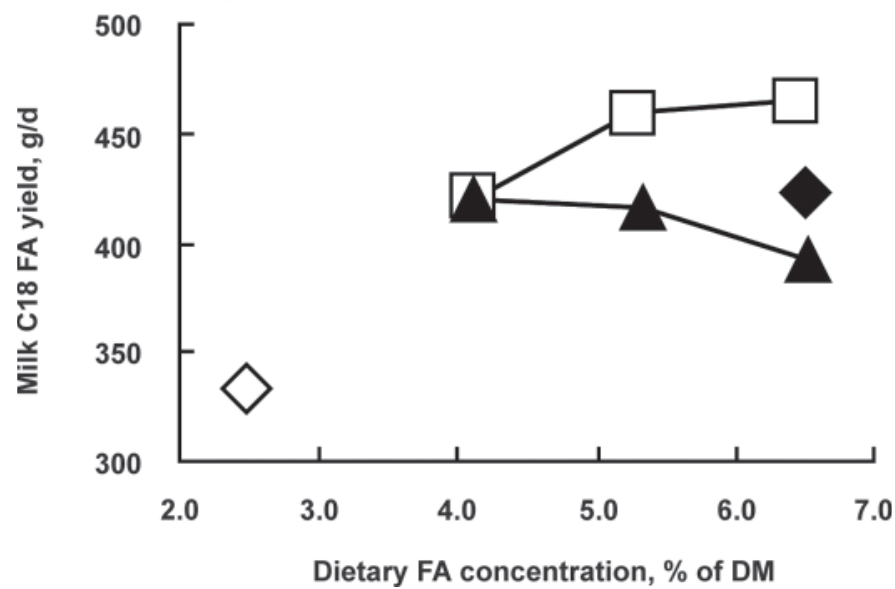

Figure 2. Effect of feeding increasing levels of $\mathrm{C} 18: 1$ or $\mathrm{C} 18: 2$ on a) milk fat yield, b) milk $\mathrm{C}<16 \mathrm{FA}$ yield, and c) milk total $\mathrm{C} 18 \mathrm{FA}$ yield $\diamond$ : No fat; $:$ MOML; $\square$ : LOLL-MOLL-HOLL (left to right), effect of increasing levels of C18:1; $\mathbf{\Delta}$ : LOLL-LOML-LOHL (left to right), effect of increasing levels of C18:2. No fat: no added fat; LOLL: low C18:1, low C18:2; LOML: low C18:1, medium C18:2; LOHL: low C18:1, high C18:2; MOLL: medium C18:1, low C18:2; MOML: medium C18:1, medium C18:2; HOLL: high C18:1, low C18:2. sistent with our results, but milk protein concentration was decreased in those studies. Milk protein concentration is a consequence of the relationship between milk yield and milk protein yield and this is normally associated with increased milk yield and due to a dilution effect instead of inhibition of protein synthesis itself (DePeters and Cant, 1992). Decreased milk protein yield by feeding $3.75 \%$ soybean oil to a low-fat diet (Banks et al., 1976) or feeding 5\% linseed oil (Chilliard et al., 2009) was also reported in the literature. Both C18:1 and C18:2 feeding decreased milk lactose yield and SNF yield, and increased milk SCC linearly. Furthermore, C18:2 feeding linearly decreased milk lactose concentration and MUN, and increased milk SNF concentration (Table 4).

The change of milk fat yield at p.m. milkings when cows were switched to another fat blend diet was presented in Figure 3. Each data point at d 0 is the average milk fat yield of the other 6 treatment diets at p.m. milking on d 21 of the previous period. Figure 3 shows greater variation in milk fat yield change during the first $11 \mathrm{~d}$ of each period. The variation still occurred thereafter through the end of each period but not as substantial as in the first $11 \mathrm{~d}$ of each period.

Body weight, BCS, DMI, milk yield, ECM yield, lactose yield, SNF yield, SCC, and MUN were not affected by monensin supplementation in this study (Table 4 ). The experimental design of this study gave less power for the monensin main effect. Other studies also showed lack of monensin effect on animal BW and BCS (Green et al., 1999), or DMI and milk yield (Bell et al., 2006; Odongo et al., 2007; AlZahal et al., 2008).

Our results showed that milk fat yield and concentration were not significantly affected by monensin feeding (Table 4). Wide variations exist for monensin effects on MFD in the literature. Monensin decreased milk fat yield (Broderick, 2004; AlZahal et al., 2008) or concentration (Phipps et al., 2000; Odongo et al., 2007) in numerous studies, but in others monensin had no significant effect on milk fat concentration (Duffield et al., 1999), or milk fat yield (Lean et al., 1994) or both (Beckett et al., 1998; Bell et al., 2006). The inconsistency in the literature could be due to the dose of monensin administered (Phipps et al., 2000), method of delivery, animal stage of lactation, or interactions with dietary factors (Duffield et al., 2008a). The mechanism by which monensin feeding affects MFD could be explained by its interference with biohydrogenation of long-chain unsaturated FA within the rumen, possibly through its effect on ruminal bacteria (Jenkins et al., 2003). Feeding monensin increased the proportions of trans-10,cis-12 CLA and trans-9,cis-11 CLA in milk fat (AlZahal et al. 2008), and these FA intermediates produced from a shifted biohydrogenation pathway 


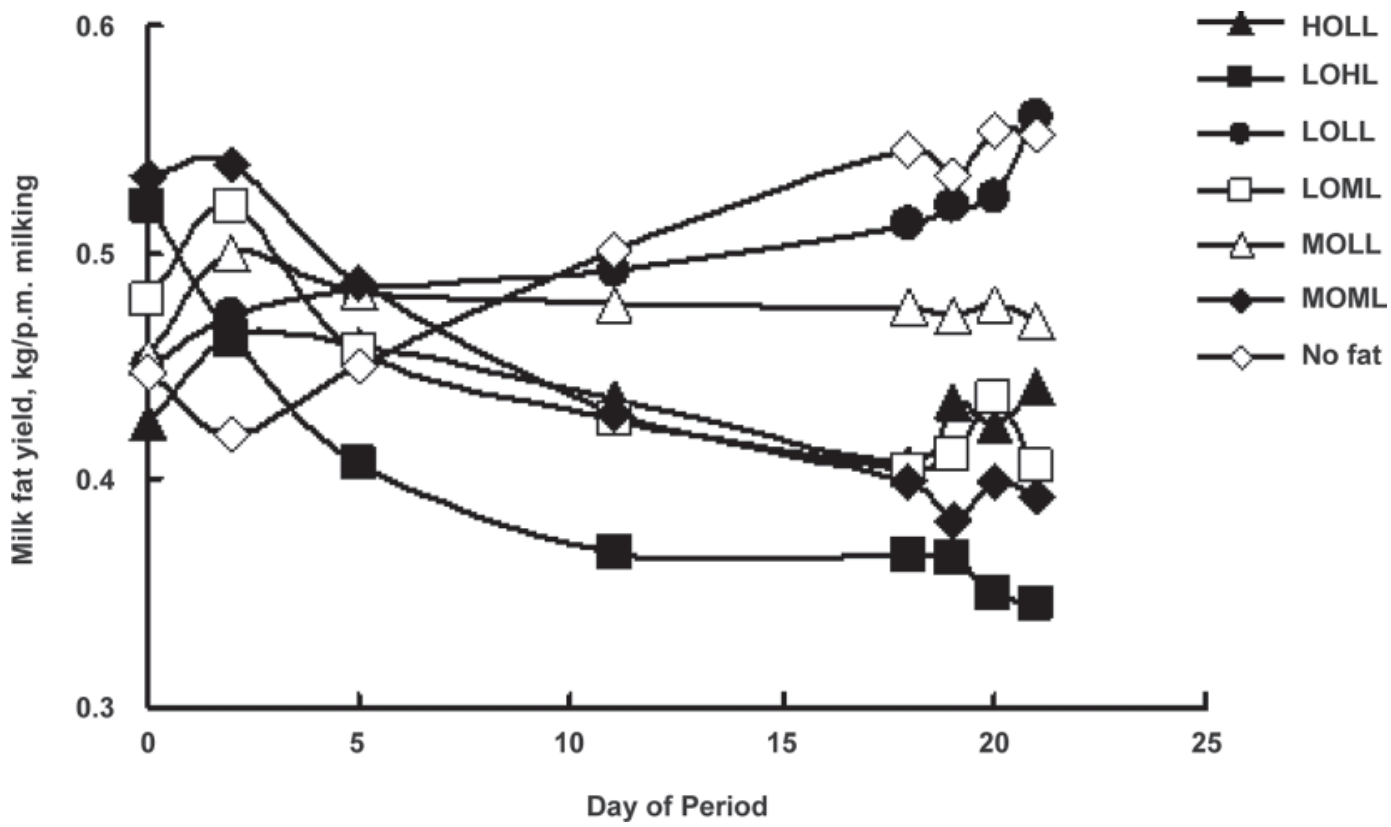

Figure 3. Fat blend effect on milk fat yield at p.m. milking (average of fat blend Latin square period 2-7). Tested on d 2, 5, 11, 18, 19, 20, and 21 of each period; $\mathrm{d} 0$ is the same as d 21 of the previous period and is the average of the other 6 fat blend treatments. $\mathbf{\Delta}$ : HOLL, high C18:1, low C18:2; 口: LOHL, low C18:1, high C18:2; ๑: LOLL, low C18:1, low C18:2; $\square$ : LOML, low C18:1, medium C18:2; $\Delta$ : MOLL, medium C18:1, low C18:2; : MOML, medium C18:1, medium C18:2; $\diamond:$ No fat, no added fat.

negatively affect de novo FA synthesis in the mammary gland (Baumgard et al., 2000; Bauman and Griinari, 2003; Perfield et al., 2007).

No evidence was found that milk protein concentration and yield were affected by monensin supplementation (Table 4). This is consistent with previous research (Duffield et al., 1999; Bell et al., 2006; AlZahal et al., 2008), although Phipps et al. (2000) reported a decrease in milk protein concentration with monensin feeding. However, increased milk yield was associated with monensin feeding in that study; thus, a decrease in milk protein concentration could merely have been a dilution effect (Phipps et al., 2000). Duffield et al. (2008a) summarized 36 papers in a meta-analysis and demonstrated increased milk protein yield with monensin feeding. However, increased milk protein yield response was often noticed with pasture-based studies or when monensin was top dressed, which suggested influence from monensin delivery method or diet type (Duffield et al., 2008a).

An interaction between monensin and fat blend or an interaction between monensin and period was not significant for any of the outcomes measured in this study (Table 4). AlZahal et al. (2008), however, found a possible interaction between monensin and soybean oil on milk fat concentration, but not on milk fat yield. Feeding monensin resulted in a more significant decrease in milk fat concentration when a greater amount of
C18:2-rich soybean oil was present in the diet (AlZahal et al., 2008). Further studies are needed to evaluate the effect of monensin on cows supplemented with oils.

\section{Milk FA Composition and Yield}

Uptake of preformed long-chain FA from peripheral circulation (dietary FA or NEFA from body fat mobilization) and de novo synthesis of short- and mediumchain FA in the mammary gland are the 2 major sources of milk FA. This study showed a decreased proportion (g/100 g of FA) of short- and medium-chain FA with less than 16 carbons $(\mathrm{C}<16)$, increased proportion of total $\mathrm{C} 18 \mathrm{FA}$, and a decreased ratio of short/long-chain FA $(\mathrm{C}<16 /$ total $\mathrm{C} 18)$ in milk fat by feeding increasing levels of C18:1 or C18:2 (Table 5). This is consistent with previous studies, which reported that inhibited de novo short- and medium-chain FA synthesis by addition of unprotected vegetable oil can be partially offset by increased delivery and uptake of long-chain FA from blood (Bell et al., 2006; Chilliard et al., 2009). Therefore, long-chain FA represent a larger proportion of milk fat, whereas the proportion of short- and medium-chain FA decreases compared with feeding diets without oil supplementation. These effects were also found when comparing no fat with LOLL. The LOLL decreased C $<16$ and C16:0 yield and increased total C18 FA yield compared with the no-fat diet (Table 6; Figure 2). This 
suggests significant potency of unsaturated FA on MFD at very low dietary levels.

The proportion of most short- and medium-chain FA (including C16:0, which is partially synthesized de novo in the mammary gland) in milk fat were linearly decreased and long-chain FA proportions were increased by feeding increasing levels of C18:2-rich soybean oil (AlZahal et al., 2008) or C18:1-rich rapeseed oil (Fearon et al., 2004). Milk $\mathrm{C}<16 \mathrm{FA}$ proportion and yield (Table 5 and Table 6; Figure 2) were decreased more significantly by C18:2 feeding than C18:1 feeding when comparing equal-fat treatments in this study (LOML vs. MOLL, and LOHL vs. HOLL), confirming our previous conclusion that $\mathrm{C} 18: 2$ is more potent than $\mathrm{C} 18: 1$ at causing MFD. In addition, milk $\mathrm{C}<16$ yield was decreased by as much as $125 \mathrm{~g} / \mathrm{d}$ when comparing LOLL to LOML, but only decreased by $48 \mathrm{~g} / \mathrm{d}$ from LOML to LOHL (Table 6 and Figure 2). This quadratic effect also suggested a more significant influence of C18:2 on MFD at lower levels. Results of this study clearly demonstrated that the increased mammary gland uptake of long-chain FA from increasing levels of C18:1 or C18:2 feeding cannot fully compensate for the decreased de novo FA synthesis.

The milk fatty acid yield and proportion of cis9,trans-11 CLA and its major precursor trans-11 C18:1 were significantly increased above those of no fat by each of the 6 fat blend diets, and the linear increase for these 2 milk FA above LOLL when dietary C18:2 was increased (Table 5 and Table 6 ) is consistent with previous research (AlZahal et al., 2008). Feeding increasing levels of C18:1 above LOLL and keeping dietary C18:2 content constant (LOLL to MOLL to HOLL) did not affect yield and proportion of trans-11 C18:1 and cis9,trans-11 CLA in the current study. Rego et al. (2009) also did not find an increase in trans-11 C18:1 and cis-9,trans-11 CLA when supplementing rapeseed oil to grazing cows. This supports $\mathrm{C} 18: 2$, but not $\mathrm{C} 18: 1$, as a major precursor of trans-11 C18:1 and cis-9,trans-11 CLA.

An increase of milk fat trans-10 C18:1 concentration has been consistently reported when unsaturated oils are added to the diet. Compared with the no-fat diet, feeding fat blend diets except for LOLL significantly decreased milk fat yield and increased the trans-10 C18:1 proportion in milk FA, which averaged $4.56 \%$ (without monensin feeding, data not shown). This percentage is close to $4.37 \%$ trans-10 C18:1 in milk fat when an abomasal infusion of a mixture of C18:1 fatty acid methyl esters supplied $92.1 \mathrm{~g} / \mathrm{d}$ of trans-10 C18:1 and decreased milk fat secretion (Shingfield et al., 2009). Therefore, it is proposed that trans-10 C18:1 may contribute to the diet-induced MFD when supplied in greater amounts to the mammary gland (Shingfield et al., 2009), considering that C18:1 feeding linearly increased trans-10 $\mathrm{C} 18: 1$ proportion and yield in milk fat and decreased milk fat yield in the current study (Tables 4, 5, and 6; Figure 2). However, we cannot rule out the possibility that the milk fat-depressing effect of feeding increasing levels of C18:1 might come from other anti-lipogenic CLA, such as trans-9, cis-11 CLA (Perfield et al., 2007) and cis-10,trans-12 CLA (Sæbø et al., 2005), which were not analyzed in the current study. Also, Lock et al. (2007) reported that abomasal infusion of $42.6 \mathrm{~g} / \mathrm{d}$ of trans-10 C18:1 did not decrease milk fat synthesis, but the trans-10 C18:1 proportion in milk FA after infusion was only $1.11 \%$.

Trans-10,cis-12 CLA is formed from a putative pathway for the biohydrogenation of C18:2 to form trans-10 C18:1 and is a potent inhibitor of milk fat synthesis (Bauman and Griinari, 2001). Increasing dietary C18:1 when C18:2 was constant (LOLL to MOLL to HOLL) only linearly increased yield and proportion of trans-10 C18:1 but did not affect yield and proportion of trans10,cis-12 CLA. This suggested that trans-10,cis-12 CLA was not increased due to C18:1 feeding and did not cause reduced fat synthesis with added dietary C18:1. Postruminal infusion of trans-10 C18:1 also did not affect milk trans-10,cis-12 CLA concentration (Lock et al., 2007). Increasing levels of C18:2 in the diet linearly increased trans-10, cis-12 CLA yield in milk fat in this study (Table 6). Cruz-Hernandez et al. (2007) and AlZahal et al. (2008) similarly reported that both proportions of trans-10 C18:1 and trans-10,cis-12 CLA in milk FA were increased by increasing levels of sunflower oil feeding.

Although feeding low levels of C18:1 and C18:2 (LOLL) did not inhibit milk fat yield compared with that of the no-fat diet (1.13 vs. $1.17 \mathrm{~kg} / \mathrm{d}$, respectively), increased total $\mathrm{C} 18$ secretion, and decreased $\mathrm{C}<16$ secretion and $\mathrm{C}<16 /$ total $\mathrm{C} 18$ ratio by feeding LOLL still indicated an altered rumen biohydrogenation pathway and decreased de novo synthesis of FA in the mammary gland (Figure 2). The absorption of dietary long-chain FA into milk fat is able to compensate for the inhibited de novo FA synthesis in the mammary gland when the diet contains less unsaturated FA. Dietary C18:1 and C18:2 contents both increased by $0.62 \%$ for LOLL versus no fat, but LOLL feeding only increased trans-10 C18:1 yield without any effect on trans-10,cis-12 CLA. This also suggests the potential anti-lipogenic effect of trans-10 C18:1, which may inhibit the de novo $\mathrm{C}<16$ synthesis for LOLL, although other bioactive FA not measured in this study, and correlated with trans-10 C18:1, may also be responsible.

A significant C18:1 $\times$ C18:2 interaction was found on milk FA $\mathrm{C}<16$ proportion and proportion and yield of total $\mathrm{C} 18$ in milk FA (Table 5 and 6). In general, 
Table 5. Effect of fat blend and monensin (Mon) supplementation on milk fatty acid (FA) composition

\begin{tabular}{|c|c|c|c|c|c|c|c|c|c|c|c|c|c|c|c|c|c|c|c|c|}
\hline \multirow[b]{2}{*}{$\begin{array}{l}\mathrm{FA},{ }^{1} \\
\mathrm{~g} / 100 \mathrm{~g} \\
\text { of } \mathrm{FA}\end{array}$} & \multicolumn{7}{|c|}{ Fat blend treatment ${ }^{2}$} & \multicolumn{4}{|c|}{ Monensin } & \multicolumn{9}{|c|}{$P$-value ${ }^{4}$} \\
\hline & No fat & LOLL & LOML & LOHL & MOLL & MOML & HOLL & $\mathrm{SEM}^{3}$ & Mon- & Mon+ & SEM & $\begin{array}{c}\text { C18:1, } \\
\text { L }\end{array}$ & $\begin{array}{c}\text { C18:1, } \\
\text { Q }\end{array}$ & $\begin{array}{c}\mathrm{C} 18: 2, \\
\mathrm{~L}\end{array}$ & $\begin{array}{c}\text { C18:2, } \\
\text { Q }\end{array}$ & $\begin{array}{c}\text { C18:1 } \\
\times \text { C18:2 }\end{array}$ & $\begin{array}{l}\text { No fat } \\
\text { vs. } \\
\text { LOLL }\end{array}$ & Mon & $\begin{array}{l}\text { Mon } \\
\times \text { oil }\end{array}$ & $\begin{array}{l}\text { Mon } \\
\times \text { par }\end{array}$ \\
\hline $4: 0$ & $3.62^{\mathrm{a}}$ & $3.71^{\mathrm{a}}$ & $2.56^{\mathrm{cd}}$ & $2.13^{\mathrm{d}}$ & $3.07^{\mathrm{b}}$ & $2.35^{\mathrm{d}}$ & $2.88^{\mathrm{bc}}$ & 0.15 & 3.06 & 2.74 & 0.14 & $<0.01$ & 0.12 & $<0.01$ & 0.01 & 0.06 & 0.60 & 0.11 & 0.09 & 0.51 \\
\hline $6: 0$ & $2.31^{\mathrm{a}}$ & $2.04^{\mathrm{b}}$ & $1.24^{\mathrm{de}}$ & $1.00^{\mathrm{f}}$ & $1.60^{\mathrm{c}}$ & $1.04^{\mathrm{ef}}$ & $1.33^{\mathrm{d}}$ & 0.07 & 1.61 & 1.42 & 0.07 & $<0.01$ & 0.16 & $<0.01$ & $<0.01$ & 0.01 & $<0.01$ & 0.05 & 0.16 & 0.34 \\
\hline $8: 0$ & $1.53^{\mathrm{a}}$ & $1.24^{\mathrm{b}}$ & $0.68^{\mathrm{d}}$ & $0.53^{\mathrm{e}}$ & $0.91^{\mathrm{c}}$ & $0.55^{\mathrm{e}}$ & $0.72^{\mathrm{d}}$ & 0.04 & 0.95 & 0.81 & 0.04 & $<0.01$ & 0.07 & $<0.01$ & $<0.01$ & $<0.01$ & $<0.01$ & 0.02 & 0.41 & 0.35 \\
\hline 10:0 & $3.64^{\mathrm{a}}$ & $2.67^{\mathrm{b}}$ & $1.46^{\mathrm{d}}$ & $1.14^{\mathrm{e}}$ & $1.91^{\mathrm{c}}$ & $1.18^{\mathrm{e}}$ & $1.48^{\mathrm{d}}$ & 0.08 & 2.08 & 1.77 & 0.08 & $<0.01$ & 0.03 & $<0.01$ & $<0.01$ & $<0.01$ & $<0.01$ & $<0.01$ & 0.43 & 0.50 \\
\hline $12: 0$ & $4.36^{\mathrm{a}}$ & $3.09^{\mathrm{b}}$ & $1.98^{\mathrm{d}}$ & $1.62^{\mathrm{f}}$ & $2.28^{\mathrm{c}}$ & $1.68^{\mathrm{ef}}$ & $1.92^{\mathrm{de}}$ & 0.08 & 2.58 & 2.25 & 0.07 & $<0.01$ & $<0.01$ & $<0.01$ & $<0.01$ & $<0.01$ & $<0.01$ & $<0.01$ & 0.21 & 0.91 \\
\hline 14:0 & $12.29^{\mathrm{a}}$ & $10.67^{\mathrm{b}}$ & $8.58^{\mathrm{d}}$ & $7.51^{\mathrm{f}}$ & $9.30^{\mathrm{c}}$ & $7.77^{\mathrm{ef}}$ & $8.31^{\mathrm{de}}$ & 0.17 & 9.43 & 8.98 & 0.16 & $<0.01$ & 0.23 & $<0.01$ & $<0.01$ & 0.03 & $<0.01$ & 0.04 & 0.73 & 0.85 \\
\hline $14: 1$ & $1.26^{\mathrm{a}}$ & $1.23^{\mathrm{a}}$ & $1.30^{\mathrm{a}}$ & $0.98^{\mathrm{b}}$ & $1.24^{\mathrm{a}}$ & $1.19^{\mathrm{a}}$ & $1.23^{\mathrm{a}}$ & 0.06 & 1.22 & 1.19 & 0.06 & 0.99 & 0.85 & $<0.01$ & $<0.01$ & 0.19 & 0.69 & 0.81 & 0.55 & 0.25 \\
\hline 15:0 & $1.30^{\mathrm{a}}$ & $1.01^{\mathrm{b}}$ & $0.88^{\mathrm{c}}$ & $0.78^{\mathrm{d}}$ & $0.90^{\mathrm{c}}$ & $0.79^{\mathrm{d}}$ & $0.81^{\mathrm{d}}$ & 0.02 & 0.93 & 0.92 & 0.02 & $<0.01$ & 0.52 & $<0.01$ & 0.29 & 0.40 & $<0.01$ & 0.65 & 0.10 & 0.75 \\
\hline$<16: 0^{5}$ & $31.81^{\mathrm{a}}$ & $26.83^{\mathrm{b}}$ & $19.52^{\mathrm{d}}$ & $16.37^{\mathrm{e}}$ & $22.17^{\mathrm{c}}$ & $17.25^{\mathrm{e}}$ & $19.46^{\mathrm{d}}$ & 0.46 & 22.86 & 20.98 & 0.40 & $<0.01$ & 0.03 & $<0.01$ & $<0.01$ & $<0.01$ & $<0.01$ & $<0.01$ & 0.50 & 0.58 \\
\hline 16:0 & $32.04^{\mathrm{a}}$ & $26.45^{\mathrm{b}}$ & $22.98^{\mathrm{c}}$ & $21.03^{\mathrm{d}}$ & $23.06^{\mathrm{c}}$ & $21.09^{\mathrm{d}}$ & $21.04^{\mathrm{d}}$ & 0.35 & 24.12 & 23.79 & 0.30 & $<0.01$ & 0.04 & $<0.01$ & 0.03 & $<0.01$ & $<0.01$ & 0.44 & 0.78 & 0.42 \\
\hline $16: 1 \quad c-9$ & $1.70^{\mathrm{ab}}$ & $1.54^{\mathrm{b}}$ & $1.90^{\mathrm{a}}$ & $1.65^{\mathrm{ab}}$ & $1.58^{\mathrm{b}}$ & $1.85^{\mathrm{ab}}$ & $1.68^{\mathrm{ab}}$ & 0.09 & 1.66 & 1.74 & 0.08 & 0.19 & 0.73 & 0.27 & $<0.01$ & 0.54 & 0.14 & 0.51 & 0.55 & 0.22 \\
\hline $17: 0$ & $0.60^{\mathrm{a}}$ & $0.54^{\mathrm{b}}$ & $0.46^{\mathrm{c}}$ & $0.40^{\mathrm{d}}$ & $0.47^{\mathrm{c}}$ & $0.39^{\mathrm{d}}$ & $0.40^{\mathrm{d}}$ & 0.01 & 0.46 & 0.47 & 0.01 & $<0.01$ & 0.85 & $<0.01$ & 0.62 & 0.75 & $<0.01$ & 0.57 & 0.53 & 0.43 \\
\hline 18:0 & $6.72^{\mathrm{d}}$ & $9.23^{\mathrm{c}}$ & $9.70^{\mathrm{bc}}$ & $10.05^{\mathrm{bc}}$ & $10.44^{\mathrm{ab}}$ & $10.38^{\mathrm{ab}}$ & $10.95^{\mathrm{a}}$ & 0.26 & 9.70 & 9.57 & 0.24 & $<0.01$ & 0.13 & $<0.01$ & 0.79 & 0.15 & $<0.01$ & 0.70 & 0.48 & 0.27 \\
\hline $18: 1$, total & $19.17^{\mathrm{d}}$ & $26.77^{\mathrm{c}}$ & $35.49^{\mathrm{b}}$ & $39.53^{\mathrm{a}}$ & $34.00^{\mathrm{b}}$ & $39.90^{\mathrm{a}}$ & $38.78^{\mathrm{a}}$ & 0.48 & 32.45 & 34.30 & 0.41 & $<0.01$ & $<0.01$ & $<0.01$ & $<0.01$ & $<0.01$ & $<0.01$ & $<0.01$ & 0.93 & 0.19 \\
\hline$t-4$ & $0.039^{\mathrm{c}}$ & $0.047^{\mathrm{bc}}$ & $0.049^{\mathrm{bc}}$ & $0.036^{\mathrm{c}}$ & $0.074^{\mathrm{ab}}$ & $0.073^{\mathrm{ab}}$ & $0.091^{\mathrm{a}}$ & 0.007 & 0.056 & 0.061 & 0.004 & $<0.01$ & 0.59 & 0.29 & 0.42 & 0.85 & 0.43 & 0.43 & 0.09 & 0.97 \\
\hline$t-5$ & 0.11 & 0.05 & 0.35 & 0.30 & 0.10 & 0.11 & 0.15 & 0.12 & 0.22 & 0.12 & 0.07 & 0.58 & 0.97 & 0.14 & 0.20 & 0.20 & 0.75 & 0.31 & 0.69 & 0.35 \\
\hline$t-6$ to 8 & $0.18^{\mathrm{e}}$ & $0.47^{\mathrm{d}}$ & $0.80^{\mathrm{c}}$ & $0.93^{\mathrm{b}}$ & $0.90^{\mathrm{b}}$ & $1.08^{\mathrm{a}}$ & $1.16^{\mathrm{a}}$ & 0.02 & 0.77 & 0.81 & 0.01 & $<0.01$ & $<0.01$ & $<0.01$ & $<0.01$ & $<0.01$ & $<0.01$ & 0.04 & 0.36 & 0.37 \\
\hline$t-9$ & $0.20^{\mathrm{e}}$ & $0.40^{\mathrm{d}}$ & $0.73^{\mathrm{bc}}$ & $0.87^{\mathrm{a}}$ & $0.65^{\mathrm{c}}$ & $0.85^{\mathrm{ab}}$ & $0.84^{\mathrm{ab}}$ & 0.03 & 0.64 & 0.66 & 0.02 & $<0.01$ & 0.45 & $<0.01$ & 0.01 & 0.04 & $<0.01$ & 0.33 & 0.73 & 0.50 \\
\hline$t-10$ & $0.82^{\mathrm{e}}$ & $1.66^{\mathrm{e}}$ & $5.05^{\mathrm{c}}$ & $7.81^{\mathrm{a}}$ & $3.57^{\mathrm{d}}$ & $6.62^{\mathrm{b}}$ & $4.86^{\mathrm{c}}$ & 0.29 & 3.52 & 5.16 & 0.23 & $<0.01$ & 0.29 & $<0.01$ & 0.28 & 0.47 & 0.02 & $<0.01$ & $<0.01$ & 0.17 \\
\hline$t-11$ & $0.74^{\mathrm{d}}$ & $1.93^{\mathrm{c}}$ & $3.07^{\mathrm{b}}$ & $4.68^{\mathrm{a}}$ & $2.31^{\mathrm{c}}$ & $3.12^{\mathrm{b}}$ & $2.02^{\mathrm{c}}$ & 0.18 & 2.45 & 2.66 & 0.16 & 0.68 & 0.05 & $<0.01$ & 0.18 & 0.24 & $<0.01$ & 0.33 & 0.05 & 0.20 \\
\hline$t-12$ & $0.27^{\mathrm{d}}$ & $0.43^{\mathrm{cd}}$ & $0.72^{\mathrm{ab}}$ & $0.80^{\mathrm{a}}$ & $0.58^{\mathrm{bc}}$ & $0.81^{\mathrm{a}}$ & $0.82^{\mathrm{a}}$ & 0.04 & 0.59 & 0.68 & 0.02 & $<0.01$ & 0.34 & $<0.01$ & 0.04 & 0.53 & $<0.01$ & 0.02 & 0.56 & 0.18 \\
\hline$c-9$ & $14.57^{\mathrm{e}}$ & $18.54^{\mathrm{d}}$ & $20.56^{\mathrm{c}}$ & $19.61^{\mathrm{cd}}$ & $22.68^{\mathrm{b}}$ & $23.65^{\mathrm{b}}$ & $25.64^{\mathrm{a}}$ & 0.36 & 20.76 & 20.74 & 0.33 & $<0.01$ & 0.09 & $<0.01$ & $<0.01$ & 0.06 & $<0.01$ & 0.95 & 0.10 & 0.35 \\
\hline$c-11$ & $0.74^{\mathrm{e}}$ & $0.96^{\mathrm{d}}$ & $1.13^{\mathrm{ab}}$ & $1.22^{\mathrm{a}}$ & $1.00^{\mathrm{cd}}$ & $1.13^{\mathrm{ab}}$ & $1.06^{\mathrm{bc}}$ & 0.03 & 1.00 & 1.06 & 0.02 & $<0.01$ & 0.83 & $<0.01$ & 0.11 & 0.29 & $<0.01$ & 0.03 & 0.61 & 0.24 \\
\hline$c-12$ & $0.41^{\mathrm{e}}$ & $0.75^{\mathrm{c}}$ & $1.14^{\mathrm{b}}$ & $1.36^{\mathrm{a}}$ & $0.58^{\mathrm{d}}$ & $0.74^{\mathrm{c}}$ & $0.47^{\mathrm{de}}$ & 0.03 & 0.81 & 0.75 & 0.02 & $<0.01$ & 0.30 & $<0.01$ & 0.02 & $<0.01$ & $<0.01$ & 0.09 & 0.02 & 0.12 \\
\hline$c-13$ & 0.12 & 0.10 & 0.14 & 0.11 & 0.11 & 0.11 & 0.13 & 0.01 & 0.11 & 0.12 & 0.01 & 0.09 & 0.97 & 0.44 & 0.03 & 0.08 & 0.22 & 0.39 & 0.36 & 0.39 \\
\hline $\begin{array}{l}c-14 \\
+t-16\end{array}$ & $0.33^{\mathrm{d}}$ & $0.43^{\mathrm{abc}}$ & $0.48^{\mathrm{ab}}$ & $0.50^{\mathrm{a}}$ & $0.41^{\mathrm{bcd}}$ & $0.42^{\mathrm{bc}}$ & $0.40^{\mathrm{cd}}$ & 0.02 & 0.44 & 0.41 & 0.01 & 0.16 & 0.79 & 0.02 & 0.47 & 0.25 & $<0.01$ & 0.03 & 0.25 & 0.72 \\
\hline$c-15$ & $0.17^{\mathrm{d}}$ & $0.24^{\mathrm{abc}}$ & $0.30^{\mathrm{a}}$ & $0.27^{\mathrm{ab}}$ & $0.22^{\mathrm{bcd}}$ & $0.21^{\text {bcd }}$ & $0.18^{\mathrm{cd}}$ & 0.02 & 0.22 & 0.24 & 0.01 & $<0.01$ & 0.50 & 0.26 & 0.01 & 0.02 & $<0.01$ & 0.27 & 0.19 & 0.10 \\
\hline $18: 2$ n-6 & $2.92^{\mathrm{ef}}$ & $3.19^{\mathrm{cd}}$ & $3.79^{\mathrm{b}}$ & $4.04^{\mathrm{a}}$ & $2.99^{\mathrm{de}}$ & $3.32^{\mathrm{c}}$ & $2.72^{\mathrm{f}}$ & 0.07 & 3.15 & 3.42 & 0.06 & $<0.01$ & 0.62 & $<0.01$ & 0.02 & 0.02 & $<0.01$ & $<0.01$ & 0.98 & 0.10 \\
\hline $18: 3 n-3$ & $0.67^{\mathrm{a}}$ & $0.62^{\mathrm{b}}$ & $0.57^{\mathrm{c}}$ & $0.54^{\mathrm{cd}}$ & $0.57^{\mathrm{c}}$ & $0.51^{\mathrm{d}}$ & $0.52^{\mathrm{d}}$ & 0.01 & 0.56 & 0.58 & 0.01 & $<0.01$ & 0.98 & $<0.01$ & 0.24 & 0.57 & $<0.01$ & 0.06 & 0.63 & 0.95 \\
\hline $\begin{array}{c}c-9, t-11 \\
\text { CLA }\end{array}$ & $0.51^{\mathrm{d}}$ & $1.07^{\mathrm{c}}$ & $1.74^{\mathrm{b}}$ & $2.52^{\mathrm{a}}$ & $1.24^{\mathrm{c}}$ & $1.75^{\mathrm{b}}$ & $1.15^{\mathrm{c}}$ & 0.10 & 1.43 & 1.43 & 0.09 & 0.48 & 0.17 & $<0.01$ & 0.53 & 0.32 & $<0.01$ & 0.99 & 0.24 & 0.62 \\
\hline $\begin{array}{c}t-10, c-12 \\
\text { CLA }\end{array}$ & $0.026^{\mathrm{e}}$ & $0.042^{\mathrm{de}}$ & $0.067^{\mathrm{bc}}$ & $0.121^{\mathrm{a}}$ & $0.044^{\text {cde }}$ & $0.086^{\mathrm{b}}$ & $0.055^{\mathrm{cd}}$ & 0.006 & 0.054 & 0.072 & 0.005 & 0.11 & 0.53 & $<0.01$ & 0.04 & 0.15 & 0.06 & 0.01 & 0.09 & 0.59 \\
\hline Total C18 ${ }^{6}$ & $30.28^{\mathrm{f}}$ & $41.27^{\mathrm{e}}$ & $51.74^{\mathrm{c}}$ & $57.18^{\mathrm{a}}$ & $49.58^{\mathrm{d}}$ & $56.25^{\mathrm{ab}}$ & $54.43^{\mathrm{b}}$ & 0.58 & 47.67 & 49.68 & 0.53 & $<0.01$ & $<0.01$ & $<0.01$ & $<0.01$ & $<0.01$ & $<0.01$ & 0.01 & 0.97 & 0.52 \\
\hline $\begin{array}{l}<16: 0 / \\
\text { total C18 }\end{array}$ & $1.07^{\mathrm{a}}$ & $0.67^{\mathrm{b}}$ & $0.38^{\mathrm{d}}$ & $0.29^{\mathrm{f}}$ & $0.45^{\mathrm{c}}$ & $0.31^{\mathrm{ef}}$ & $0.36^{\mathrm{de}}$ & 0.02 & 0.54 & 0.47 & 0.01 & $<0.01$ & $<0.01$ & $<0.01$ & $<0.01$ & $<0.01$ & $<0.01$ & $<0.01$ & 0.24 & 0.53 \\
\hline $20: 0$ & 0.072 & 0.079 & 0.086 & 0.087 & 0.084 & 0.081 & 0.067 & 0.006 & 0.081 & 0.078 & 0.004 & 0.12 & 0.11 & 0.31 & 0.60 & 0.34 & 0.39 & 0.57 & 0.43 & 0.68 \\
\hline Unknown & 1.90 & 1.80 & 1.90 & 1.89 & 1.69 & 1.79 & 1.71 & 0.06 & 1.77 & 1.85 & 0.03 & 0.27 & 0.35 & 0.32 & 0.43 & 0.99 & 0.25 & 0.07 & 0.96 & 0.72 \\
\hline \multicolumn{21}{|c|}{$\begin{array}{l}{ }^{\mathrm{a}-\mathrm{f}} \text { Least squares means within a row not sharing a common superscript letter differ }(P<0.05) \text { for oil effect according to the Bonferroni test. } \\
{ }^{1} c=\text { cis; } t=\text { trans. }\end{array}$} \\
\hline \multicolumn{21}{|c|}{$\begin{array}{l}{ }^{2} \text { No fat: without fat blend; LOLL: low C18:1, low C18:2; LOML: low C18:1, medium C18:2; LOHL: low C18:1, high C18:2; MOLL: medium C18:1, low C18:2; MOML: medium } \\
\text { C18:1, medium C18:2; HOLL: high C18:1, low C18:2. }\end{array}$} \\
\hline \multirow{3}{*}{\multicolumn{21}{|c|}{$\begin{array}{l}{ }^{3} \text { Standard error of the means for calculated statis } \\
{ }^{4} \text { L: linear effect; Q: quadratic effect; par: parity. } \\
{ }^{5}<16: 0 \text { : sum of FA with } 4 \text { to } 15 \text { carbons. }\end{array}$}} \\
\hline & & & & & & & & & & & & & & & & & & & & \\
\hline & & & & & & & & & & & & & & & & & & & & \\
\hline & & & & & & & & & & & & & & & & & & & & \\
\hline
\end{tabular}


Fat blend treatments ${ }^{3}$

Monensin

$P$-value ${ }^{5}$

${ }^{2}$

LOML LOHL MOLL MOML HOLL SEM ${ }^{4}$ Mon- Mon+ SEM C18: C18:1 No fat

\begin{tabular}{|c|c|c|c|c|c|c|c|c|c|c|c|c|c|c|c|c|c|c|c|c|}
\hline $\mathrm{g} / \mathrm{d}$ & No fat & LOLL & LOML & LOHL & MOLL & MOML & HOLL & $\mathrm{SEM}^{4}$ & Mon- & Mon+ & SEM & L & Q & L & $\mathrm{Q}$ & $\widehat{\mathrm{C} 18: 2}$ & LOLL & Mon & $\times$ oil & par \\
\hline 4:0 & $41.86^{\mathrm{a}}$ & $40.18^{\mathrm{a}}$ & $21.58^{\mathrm{bcd}}$ & $15.32^{\mathrm{d}}$ & $29.33^{\mathrm{b}}$ & $19.03^{\mathrm{cd}}$ & $26.00^{\mathrm{bc}}$ & 2.68 & 29.95 & 25.28 & 2.80 & $<0.01$ & 0.09 & $<0.01$ & $<0.01$ & 0.02 & 0.54 & 0.24 & 0.46 & 0.51 \\
\hline 0.0 & 2 & $22.29^{\mathrm{b}}$ & $10.80^{\mathrm{de}}$ & $7.58^{\mathrm{e}}$ & $15.74^{\mathrm{c}}$ & $845^{\mathrm{de}}$ & $12.05^{\mathrm{cd}}$ & 1.43 & 16.18 & 13.42 & 1.57 & $<0.01$ & 0.21 & $<0.01$ & $<0.01$ & 0.02 & $<0.01$ & 0.22 & .62 & 0.43 \\
\hline $8: 0$ & $17.59^{\mathrm{a}}$ & $13.57^{\mathrm{b}}$ & $6.03^{\mathrm{d}}$ & $4.04^{\mathrm{d}}$ & $9.04^{\mathrm{c}}$ & $46^{\mathrm{d}}$ & $6.49^{\mathrm{d}}$ & 0.86 & 9.72 & 7.77 & 0.92 & $<0.01$ & 0.15 & $<0.01$ & $<0.01$ & $<0.01$ & $<0.01$ & 0.14 & .67 & 0.43 \\
\hline 10:0 & $41.88^{\mathrm{a}}$ & $29.18^{\mathrm{b}}$ & $12.81^{\mathrm{d}}$ & $8.48^{\mathrm{d}}$ & $18.93^{\mathrm{c}}$ & $9.47^{\mathrm{d}}$ & $13.18^{\mathrm{d}}$ & 1.71 & 21.29 & 16.98 & 1.78 & $<0.01$ & 0.11 & $<0.01$ & $<0.01$ & $<0.01$ & $<0.01$ & 0.09 & 0.50 & 0.51 \\
\hline 12:0 & $50.02^{\mathrm{a}}$ & $33.51^{\mathrm{b}}$ & $16.86^{\mathrm{d}}$ & $11.71^{\mathrm{d}}$ & $22.69^{\mathrm{c}}$ & $13.19^{\mathrm{d}}$ & $16.92^{\mathrm{d}}$ & 1.79 & 25.97 & 21.14 & 1.84 & $<0.01$ & 0.09 & $<0.01$ & $<0.01$ & $<0.01$ & $<0.01$ & 0.07 & 0.33 & 0.60 \\
\hline :0 & $140.05^{\mathrm{a}}$ & $114.37^{\mathrm{b}}$ & $71.68^{\mathrm{d}}$ & $52.51^{\mathrm{e}}$ & $90.35^{\mathrm{c}}$ & $59.94^{\mathrm{de}}$ & $73.02^{\mathrm{d}}$ & 5.56 & 90.63 & 81.35 & 6.13 & $<0.01$ & 0.43 & $<0.01$ & $<0.01$ & 0.08 & $<0.01$ & 0.29 & 0.98 & 0.61 \\
\hline$: 1$ & $4.14^{\mathrm{a}}$ & $13.01^{\mathrm{a}}$ & $10.47^{\mathrm{bc}}$ & $6.61^{\mathrm{d}}$ & $11.99^{\mathrm{ab}}$ & $9.03^{\mathrm{c}}$ & $10.80^{\mathrm{bc}}$ & 0.70 & 11.27 & 10.46 & 0.73 & $<0.01$ & 0.88 & $<0.01$ & 0.26 & 0.66 & 0.11 & 0.44 & 0.68 & 0.72 \\
\hline$: 0$ & $14.78^{\mathrm{a}}$ & $10.61^{\mathrm{b}}$ & $7.14^{\mathrm{cd}}$ & $5.36^{\mathrm{e}}$ & $8.41^{\mathrm{c}}$ & $5.96^{\text {de }}$ & $6.86^{\mathrm{d}}$ & 0.44 & 8.71 & 8.19 & 0.46 & $<0.01$ & 0.37 & $<0.01$ & 0.02 & 0.09 & $<0.01$ & 0.43 & 0.91 & 0.62 \\
\hline$<16: 0^{6}$ & $364.10^{\mathrm{a}}$ & $289.22^{\mathrm{b}}$ & $64.23^{\mathrm{d}}$ & $16.42^{\mathrm{e}}$ & $215.56^{\mathrm{c}}$ & $134.92^{\mathrm{de}}$ & $172.02^{\mathrm{d}}$ & 14.68 & 223.20 & 192.93 & 16.07 & $<0.01$ & 0.19 & $<0.01$ & $<0.01$ & 0.02 & $<0.01$ & 0.19 & 0.92 & 0.56 \\
\hline $16: 0$ & 3 & $285.45^{\mathrm{b}}$ & $187.71^{\mathrm{cd}}$ & $142.93^{\mathrm{e}}$ & $220.95^{\mathrm{c}}$ & $159.41^{\text {de }}$ & $179.47^{\mathrm{de}}$ & 13.21 & 228.87 & 212.12 & 14.77 & $<0.01$ & 0.25 & $<0.01$ & $<0.01$ & 0.03 & $<0.01$ & 0.42 & 0.98 & 0.52 \\
\hline $16: 1 \mathrm{c}$ & $a_{a}$ & $15.72^{\mathrm{b}}$ & $14.75^{\mathrm{b}}$ & $10.66^{\mathrm{c}}$ & $14.81^{\mathrm{b}}$ & $13.45^{\mathrm{b}}$ & $14.06^{\mathrm{b}}$ & 0.83 & 14.80 & 14.53 & 0.77 & 0. & 0.92 & $<0.01$ & 0.04 & 0.75 & $<0.01$ & 0.80 & 93 & 0.58 \\
\hline 0 & & $5.55^{\mathrm{b}}$ & & $2.75^{\mathrm{e}}$ & $4.40^{\mathrm{c}}$ & $2.89^{\mathrm{e}}$ & $3.30^{\mathrm{de}}$ & 0. & 4.26 & 4.14 & 0.23 & $<0$ & 0.88 & $<0$ & 0.04 & 0.37 & $<0.01$ & 0.72 & 7 & 0.53 \\
\hline 18:0 & & $95.08^{\mathrm{a}}$ & $78.60^{\mathrm{bc}}$ & $68.89^{\mathrm{c}}$ & 95. & $78.40^{\mathrm{bc}}$ & $92.39^{\mathrm{ab}}$ & 5.11 & 86.53 & 80.24 & 5.55 & 0.57 & 0.69 & $<0.01$ & 0.40 & 0.94 & $<0.01$ & 0.42 & 0.90 & 0.37 \\
\hline $18: 1$ total & 19 & $273.83^{\mathrm{c}}$ & $284.76^{\mathrm{bc}}$ & $269.95^{\mathrm{c}}$ & $315.99^{\mathrm{ab}}$ & $300.19^{\mathrm{abc}}$ & $332.77^{\mathrm{a}}$ & 14.19 & 283.48 & 284.43 & 16.18 & $<0.01$ & 0.22 & 0.75 & 0.22 & 0.12 & $<0.01$ & 0.97 & 86 & 0.82 \\
\hline$t-4$ & & $0.48^{\mathrm{ab}}$ & $0.41^{\mathrm{ab}}$ & $0.25^{\mathrm{b}}$ & $0.71^{\mathrm{a}}$ & $0.56^{\mathrm{ab}}$ & $079^{\mathrm{a}}$ & 0.09 & 0.51 & 0.53 & 0.06 & & & 0 . & 0.67 & 0.62 & 0. & 0.76 & 6 & 0.97 \\
\hline$t-5$ & & & & 1.72 & 0. & & 1. & 0. & 1.72 & 0.90 & 0.45 & 0.55 & 0.97 & 0.32 & 0.15 & 0.19 & 0.53 & 0.21 & 4 & 0.25 \\
\hline$t-6$ to 8 & & d & 6 . & $6.30^{\mathrm{c}}$ & $8.40^{\mathrm{b}}$ & 8.1 & $10.07^{\mathrm{a}}$ & 0. & 6.5 & 6.57 & 0.42 & $<0.01$ & $<0.01$ & $<0.01$ & 0.02 & $<0.01$ & $<0.01$ & 0.99 & 2 & 0.82 \\
\hline$t-9$ & & $4.05^{\mathrm{c}}$ & $5.91^{\mathrm{b}}$ & $6.03^{\mathrm{ab}}$ & $5.97^{\mathrm{b}}$ & $6.49^{\mathrm{ab}}$ & $7.23^{\mathrm{a}}$ & 0 . & 5. & 5.38 & 0.37 & $<0$ & 4 & $<0$ & 0.01 & 0.02 & $<0.01$ & 0.94 & 0.75 & 0.99 \\
\hline$t-10$ & 7 & $15.83^{\mathrm{d}}$ & $39.57^{\mathrm{bc}}$ & $49.86^{\mathrm{a}}$ & $33.17^{\mathrm{c}}$ & $49.23^{\mathrm{a}}$ & $42.57^{\mathrm{ab}}$ & 2.70 & 28.07 & 39.97 & 2.50 & $<0.0$ & 0.11 & $<0.01$ & $<0.01$ & 0.06 & 0.01 & $<0.01$ & 0.21 & 0.34 \\
\hline$t-11$ & 8 & $19.67^{\mathrm{bc}}$ & $25.64^{\mathrm{b}}$ & $34.80^{\mathrm{a}}$ & $21.78^{\mathrm{bc}}$ & $24.58^{\mathrm{bc}}$ & $17.63^{\mathrm{c}}$ & 2.54 & 21.65 & 21.86 & 2.55 & & 0.15 & $<0.01$ & 0.47 & 0.37 & $<0.01$ & 0.95 & 0.21 & 0.32 \\
\hline$t-12$ & & 4.3 & & $5.79^{\mathrm{ab}}$ & $5.67^{\mathrm{ab}}$ & $5.92^{\mathrm{ab}}$ & $7.03^{\mathrm{a}}$ & 0. & 5 & - & 0.37 & $<0$ & 0.94 & $<$ & 0.07 & 0.08 & 0.01 & 0.36 & 6 & 0.67 \\
\hline$c-9$ & $60.83^{\mathrm{d}}$ & $190.65^{\mathrm{bc}}$ & $164.27^{\mathrm{d}}$ & $133.08^{\mathrm{e}}$ & $210.03^{\mathrm{ab}}$ & $177.35^{\mathrm{cd}}$ & $219.23^{\mathrm{a}}$ & 8.76 & 184.07 & 174.62 & 9.98 & $<0.01$ & 0.43 & $<0.01$ & 0.71 & 0.55 & $<0.01$ & 0.50 & 0.52 & 0.76 \\
\hline$c-11$ & $8.22^{\mathrm{b}}$ & $9.74^{\mathrm{a}}$ & $9.14^{\mathrm{ab}}$ & $8.39^{\mathrm{ab}}$ & $9.36^{\mathrm{ab}}$ & $8.40^{\mathrm{ab}}$ & $8.90^{\mathrm{ab}}$ & 0.47 & 8.85 & 8.90 & 0.51 & 0.06 & 0.92 & $<0.01$ & 0.85 & 0.56 & $<0.01$ & 0.94 & 0.65 & 0.85 \\
\hline$c-12$ & b & $816^{\mathrm{a}}$ & 9 & $9.67^{\mathrm{a}}$ & $5.52^{\mathrm{b}}$ & $5.71^{\mathrm{b}}$ & $3.94^{\mathrm{b}}$ & & & & 0.55 & $<0$ & & & 0.25 & 0.16 & $<0.01$ & 9 & & 0.93 \\
\hline$c-13$ & & $0.99^{\mathrm{ab}}$ & $1.16^{\mathrm{ab}}$ & $0.76^{\mathrm{b}}$ & $1.11^{\mathrm{ab}}$ & $0.91^{\mathrm{ab}}$ & $1.18^{\mathrm{ab}}$ & 0.16 & 1.08 & 1.09 & 0.08 & 0.38 & 0.88 & 0.29 & 0.12 & 0.20 & 0.03 & 0.97 & 0.39 & 0.72 \\
\hline $\begin{array}{l}c-14 \\
+t-1\end{array}$ & $25-\mathrm{ab}$ & $4.45^{\mathrm{a}}$ & $3.98^{\mathrm{ab}}$ & $3.50^{\mathrm{ab}}$ & $3.81^{\mathrm{ab}}$ & $3.15^{\mathrm{b}}$ & $3.37^{\mathrm{ab}}$ & 0.30 & 3.97 & 3.40 & 0.28 & $<0.01$ & 0.72 & $<0.01$ & 0.98 & 0.67 & $<0.01$ & 0.15 & 0.32 & 0.54 \\
\hline c-15 & $3^{\mathrm{abc}}$ & & & 1.01 & 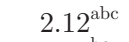 & & $1.57^{\mathrm{c}}$ & & & & 0.13 & $<0$ & & & 0.3 & 0.33 & $<0.0$ & 0.74 & 5 & 0.44 \\
\hline $18: 2 \mathrm{n}-6$ & $7^{\mathrm{a}}$ & $32.93^{\mathrm{a}}$ & $30.55^{\mathrm{ab}}$ & $28.07^{\mathrm{bc}}$ & $27.94^{\mathrm{bc}}$ & $25.17^{\mathrm{cd}}$ & $23.48^{\mathrm{d}}$ & 1.48 & 28.22 & 29.21 & 1.64 & $<0.01$ & 0.82 & $<0.01$ & 0.9 & 0.84 & 0.96 & 0.67 & 6 & 0.97 \\
\hline $18: 3 n-3$ & & $6.37^{\mathrm{b}}$ & $4.66^{\mathrm{cd}}$ & $3.81^{\mathrm{e}}$ & $5.31^{\mathrm{c}}$ & $3.81^{\mathrm{e}}$ & $4.40^{\mathrm{de}}$ & 0.2 & 5. & 5 . & 0.29 & $<0$. & 0 & $<0$ & 0.05 & 0.56 & $<0.01$ & 0.94 & 7 & 0.77 \\
\hline $\begin{array}{c}c-9, t-11 \\
\text { CLA }\end{array}$ & 5 & 10.8 & 14.2 & $18.95^{\mathrm{a}}$ & 11.8 & 13.7 & 10.1 & 1.31 & 12.57 & 11.82 & 1.30 & 0.58 & 0.24 & $<0.01$ & 0.56 & 0.42 & $<0.01$ & 0.68 & 0.27 & 0.49 \\
\hline $\begin{array}{l}t-10, \\
c-12 \text { CL }-\end{array}$ & $30^{\mathrm{d}}$ & $40^{c}$ & $52^{\mathrm{bc}}$ & $0.75^{\mathrm{a}}$ & $7^{\mathrm{cd}} \mathrm{C}$ & $63^{\mathrm{ab}}$ & $45^{\mathrm{bcc}}$ & 0.05 & 0.44 & 5 & 04 & 2 & 80 & 1 & 0.35 & 0 & 0.12 & 07 & 67 & 81 \\
\hline $\begin{array}{c}\text { Total } \\
\text { C18 }\end{array}$ & $334.27^{\mathrm{c}}$ & $422.92^{\mathrm{ab}}$ & $416.44^{\mathrm{ab}}$ & $392.97^{\mathrm{bc}}$ & $459.58^{\mathrm{a}}$ & $424.14^{\mathrm{ab}}$ & $465.68^{\mathrm{a}}$ & 21.54 & 419.16 & 413.98 & 24.46 & 0.02 & 0.34 & 0.11 & 0.59 & 0.27 & $<0.01$ & 0.88 & 0.90 & 0.70 \\
\hline 20:0 & & & & & & & & & & & & & & & 0.7 & & 0.8 & & 0.02 & 0.86 \\
\hline Unknown & $21.55^{\mathrm{a}}$ & $19.14^{\mathrm{ab}}$ & $15.34^{\mathrm{c}}$ & $13.30^{\mathrm{c}}$ & $16.31^{\mathrm{bc}}$ & $13.52^{\mathrm{c}}$ & $14.22^{\mathrm{c}}$ & 0.97 & 16.29 & 16.11 & 0.96 & $<0$ & 0. & $<0.01$ & 0.30 & 0.46 & 0.02 & & 0. & 0.68 \\
\hline Total &, $131.9^{\mathrm{a}}$ & $053.8^{\mathrm{ab}}$ & $814.2^{\mathrm{de}}$ & $698.3^{\mathrm{e}}$ & $944.8^{\mathrm{bc}}$ & $758.6^{\text {de }}$ & $859.5^{\mathrm{cd}}$ & 49.1 & 919.5 & 866.8 & 56.5 & $<0.01$ & 0.74 & $<0.01$ & 0.11 & 0.36 & 0.07 & 0.510 & 0.99 & 0.61 \\
\hline
\end{tabular}
Total $1,131.9^{\mathrm{a}}$ $1,053.8^{\mathrm{ab}} \quad 814.2$

${ }^{\mathrm{a} e \mathrm{e}}$ Least squares means within a row not sharing a common superscript letter differ $(P<0.05)$ for oil effect according to the Bonferroni test.

${ }^{1}$ FA yields were calculated based on the estimation that total FA account for $93.3 \%$ of milk total lipids (Glasser et al., 2007).

${ }^{2} c=$ cis; $t=$ trans.

${ }^{3}$ No fat: without fat blend; LOLL: low C18:1, low C18:2; LOML: low C18:1, medium C18:2; LOHL: low C18:1, high C18:2; MOLL: medium C18:1, low C18:2; MOML: medium C18:1, medium C18:2; HOLL: high C18:1, low C18:2.

${ }^{4}$ Standard error of the means for calculated statistical responses.

${ }^{5} \mathrm{~L}$ : linear effect; Q: quadratic effect; par: parity.

${ }^{6}<16: 0$ : sum of FA with 4 to 15 carbons.

${ }^{7}$ Total C18: sum of FA with 18 carbons. 


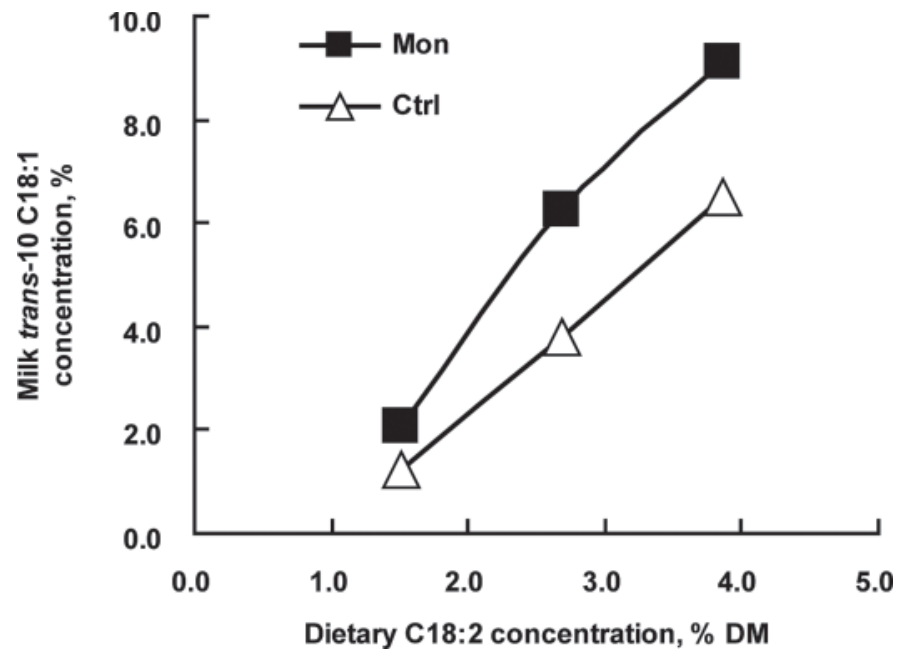

Figure 4. Significant effect of monensin $\times$ C18:2 interaction on milk trans-10 C18:1 concentration. 口: LOLL-LOML-LOHL (left to right) with $17.5 \mathrm{~g}$ of monensin/t of DM in the diet; $\Delta$ : LOLL-LOMLLOHL (left to right) without monensin in the diet. LOLL: low C18:1, low C18:2; LOML: low C18:1, medium C18:2; LOHL: low C18:1, high C18:2; Mon: diet with monensin; Ctrl: diet without monensin.

the greater decrease of $\mathrm{C}<16$ proportion and increase of total $\mathrm{C} 18$ proportion in milk FA by feeding more dietary C18:2 when C18:1 was at a low level (LOML vs. LOLL) were attenuated by increasing dietary C18:1 level (MOML vs. MOLL).

Although monensin feeding did not significantly affect milk fat yield and concentration in this study, it did increase trans-10 C18:1 proportion and yield, increase trans- 6 to 8 C18:1 and trans-10,cis-12 CLA proportion, decrease $\mathrm{C}<16 \mathrm{FA}$ proportion, and increase total $\mathrm{C} 18$ FA proportion in milk fat (Tables 5 and 6). Similar to C18:1 and C18:2 feeding, the ratio of short/long-chain FA $(\mathrm{C}<16 /$ total $\mathrm{C} 18)$ was also significantly decreased by monensin supplementation (Table 5 ). These changes suggest altered ruminal biohydrogenation of unsaturated FA and are probably an indication of increased likelihood of MFD, because trans-10,cis-12 CLA is well-known for its MFD capacity (Baumgard et al., 2002), trans-10 C18:1 is potentially anti-lipogenic when supplied at $92 \mathrm{~g} / \mathrm{d}$ (Shingfield et al., 2009), and trans-6 to $8 \mathrm{C} 18: 1$ is negatively correlated with milk fat concentration (Kadegowda et al., 2008). Our results supported those of AlZahal et al. (2008) in which monensin and soybean oil feeding also independently decreased milk FA concentration of $\mathrm{C}<16$, and increased total trans-C18:1, trans- 6 to $8 \mathrm{C} 18: 1$, trans-10 C18:1, and trans-10, cis-12 CLA proportions.

No significant interaction was found between monensin and fat on yield and proportion of most major FA or FA groups including C $<16$; C16:0; total C18:1; C18:2; cis-9,trans-11 CLA; and trans-10,cis-12 CLA
(Tables 5 and 6 ). The increase in trans-10 C18:1 proportion caused by monensin was greater when more C18:2 was added to the diet $(2.61 \%$ difference between $\mathrm{LOHL} / \mathrm{M}+$ and LOHL/M- vs. $0.86 \%$ between LOLL/ $\mathrm{M}+$ and LOLL/M-, $P=0.01$ for monensin $\times \mathrm{C} 18: 2$ interaction; Figure 4) but this same interaction did not occur with C18:1 and monensin. AlZahal et al. (2008) also reported a monensin $\times$ soybean oil interaction and showed that cows fed monensin and soybean oil together had greater proportions of total trans-C18:1; trans- 6 to $8 \mathrm{C} 18: 1$; trans-10 $\mathrm{C} 18: 1$; and trans-10,cis-12 CLA in milk fat compared with cows fed soybean oil only. Jenkins et al. (2003) found that the concentration of total trans-C18:1, especially trans-10 C18:1, increased in continuous culture of ruminal bacteria when $25 \mathrm{mg}$ of monensin $/ \mathrm{kg}$ was added. Total trans-C18:1; trans-10 C18:1; and trans-10,cis-12 CLA increased when 5\% soybean oil was added in continuous culture; however, no significant interaction of monensin and soybean oil was observed (Jenkins et al., 2003).

\section{CONCLUSIONS}

When dietary C18:1 or C18:2 were supplemented at increasing levels, milk production, milk fat concentration and yield, and proportion and yield of milk FA $\mathrm{C}<$ 16 were decreased; however, the proportion and yield of milk trans-10 C18:1 were increased. A quadratic effect for decreasing milk fat concentration and yield was found for C18:2 feeding, but not for C18:1 feeding, and was characterized by a greater decrease when C18:2 was fed from low to medium level and a smaller decrease from medium to high C18:2 level. Milk FA trans-10, cis-12 CLA proportion and yield were linearly increased by feeding increasing levels of C18:2 but not affected by feeding increasing levels of C18:1. Dietary C18:1 depressed milk fat synthesis, but was less potent than C18:2. Monensin feeding did not have any significant effects on production measures, but significantly decreased the proportion of milk FA $\mathrm{C}<16$ in milk fat. Monensin also increased milk trans-10 C18:1 proportion and yield, especially when the diet was rich in C18:2, and also increased trans-10,cis-12 CLA proportion, which showed altered ruminal biohydrogenation.

\section{ACKNOWLEDGMENTS}

The authors thank Elanco Animal Health (Greenfield, IN) for financial support for this study; Sandy Trower and all staff at Emmons Blaine Dairy Cattle Research Center (Arlington, WI) for animal feeding and sample collection; and University of Wisconsin-Madison Dairy Cattle Nutrition Laboratory Manager Sandy Bertics for milk fatty acid GC analyses. 


\section{REFERENCES}

Abdelqader, M. M., A. R. Hippen, K. F. Kalscheur, D. J. Schingoethe, and A. D. Garcia. 2009. Isolipidic additions of fat from corn germ, corn distillers grains, or corn oil in dairy cow diets. J. Dairy Sci. 92:5523-5533.

AbuGhazaleh, A. A., M. B. Riley, E. E. Thies, and T. C. Jenkins 2005. Dilution rate and $\mathrm{pH}$ effects on the conversion of oleic acid to trans C18:1 positional isomers in continuous culture. J. Dairy Sci. 88:4334-4341.

AlZahal, O., N. E. Odongo, T. Mutsvangwa, M. M. Or-Rashid, T. F Duffield, R. Bagg, P. Dick, G. Vessie, and B. W. McBride. 2008. Effects of monensin and dietary soybean oil on milk fat percentage and milk fatty acid profile in lactating dairy cows. J. Dairy Sci. 91:1166-1174.

Banks, W., J. L. Clapperton, M. E. Ferrie, and A. G. Wilson. 1976. Effect of feeding fat to dairy cows receiving a fat-deficient basal diet. I. Milk yield and composition. J. Dairy Res. 43:213-218.

Bauman, D. E., and J. M. Griinari. 2001. Regulation and nutritional manipulation of milk fat: Low-fat milk syndrome. Livest. Prod. Sci. $70: 15-29$.

Bauman, D. E., and J. M. Griinari. 2003. Nutritional regulation of milk fat synthesis. Annu. Rev. Nutr. 23:203-227.

Baumgard, L. H., B. A. Corl, D. A. Dwyer, A. Sæbø, and D. E. Bauman. 2000. Identification of the conjugated linoleic acid isomer that inhibits milk fat synthesis. Am. J. Physiol. Regul. Integr. Comp. Physiol. 278:R179-R184.

Baumgard, L. H., E. Matitashvili, B. A. Corl, D. A. Dwyer, and D. E. Bauman. 2002. Trans-10, cis-12 conjugated linoleic acid decreases lipogenic rates and expression of genes involved in milk lipid synthesis in dairy cows. J. Dairy Sci. 85:2155-2163.

Beckett, S., I. Lean, R. Dyson, W. Tranter, and L. Wade. 1998. Effects of monensin on the reproduction, health, and milk production of dairy cows. J. Dairy Sci. 81:1563-1573.

Bell, J. A., J. M. Griinari, and J. J. Kennelly. 2006. Effect of safflower oil, flaxseed oil, monensin, and vitamin $\mathrm{E}$ on concentration of conjugated linoleic acid in bovine milk fat. J. Dairy Sci. 89:733-748.

Benchaar, C., H. V. Petit, R. Berthiaume, T. D. Whyte, and P. Y. Chouinard. 2006. Effects of addition of essential oils and monensin premix on digestion, ruminal fermentation, milk production, and milk composition in dairy cows. J. Dairy Sci. 89:4352-4364.

Bergen, W. G., and D. B. Bates. 1984. Ionophores: Their effect on production efficiency and mode of action. J. Anim. Sci. 58:14651483.

Broderick, G. A. 2004. Effect of low level monensin supplementation on the production of dairy cows fed alfalfa silage. J. Dairy Sci. 87:359-368.

Chapinal, N., D. M. Veira, D. M. Weary, and M. A. G. von Keyserlingk. 2007. Technical note: Validation of a system for monitoring individual feeding and drinking behavior and intake in grouphoused cattle. J. Dairy Sci. 90:5732-5736.

Chilliard, Y., C. Martin, J. Rouel, and M. Doreau. 2009. Milk fatty acids in dairy cows fed whole crude linseed, extruded linseed, or linseed oil, and their relationship with methane output. J. Dairy Sci. 92:5199-5211.

Cruz-Hernandez, C., J. K. G. Kramer, J. J. Kennelly, D. R. Glimm, B. M. Sorensen, E. K. Okine, L. A. Goonewardene, and R. J. Weselake. 2007. Evaluating the conjugated linoleic acid and trans 18:1 isomers in milk fat of dairy cows fed increasing amounts of sunflower oil and a constant level of fish oil. J. Dairy Sci. 90:3786-3801.

DePeters, E. J., and J. P. Cant. 1992. Nutritional factors influencing the nitrogen composition of bovine milk: A review. J. Dairy Sci. 75:2043-2070.

Dhiman, T. R., L. D. Satter, M. W. Pariza, M. P. Galli, K. Albright, and M. X. Tolosa. 2000. Conjugated linoleic acid (CLA) content of milk from cows offered diets rich in linoleic and linolenic acid. J. Dairy Sci. 83:1016-1027.

Duffield, T. F., K. E. Leslie, D. Sandals, K. Lissemore, B. W. McBride, J. H. Lumsden, P. Dick, and R. Bagg. 1999. Effect of prepartum administration of monensin in a controlled-release capsule on milk production and milk components in early lactation. J. Dairy Sci 82:272-279.

Duffield, T. F., A. R. Rabiee, and I. J. Lean. 2008a. A meta-analysis of the impact of monensin in lactating dairy cattle. Part 2. Production effects. J. Dairy Sci. 91:1347-1360.

Duffield, T. F., A. R. Rabiee, and I. J. Lean. 2008b. A meta-analysis of the impact of monensin in lactating dairy cattle. Part 3. Health and reproduction. J. Dairy Sci. 91:2328-2341.

Fearon, A. M., C. S. Mayne, J. A. M. Beattie, and D. W. Bruce. 2004 Effect of level of oil inclusion in the diet of dairy cows at pasture on animal performance and milk composition and properties. J. Sci. Food Agric. 84:497-504.

Glasser, F., M. Doreau, A. Ferlay, and Y. Chilliard. 2007. Technical note: Estimation of milk fatty acid yield from milk fat data. J. Dairy Sci. 90:2302-2304.

Green, B. L., B. W. McBride, D. Sandals, K. E. Leslie, R. Bagg, and P. Dick. 1999. The impact of a monensin controlled-release capsule on subclinical ketosis in the transition dairy cow. J. Dairy Sci $82: 333-342$.

Hamilton, S., and F. Mitloehner. 2008. Environmental responses to dietary monensin in lactating dairy cows. Proc. Mitigating Air Emissions from Animal Feeding Operations Conference. Iowa State University extension and Iowa State University College of Agriculture and Life Sciences, Des Moines.

Haney, M. E., Jr., and M. M. Hoehn. 1967. Monensin, a new biologically active compound. I. Discovery and isolation. Antimicrob. Agents Chemother. 7:349-352.

He, M., and L. E. Armentano. 2011. Effect of fatty acid profile in vegetable oils and antioxidant supplementation on dairy cattle performance and milk fat depression. J. Dairy Sci. 94:2481-2491.

Jenkins, T. C. 1998. Fatty acid composition of milk from Holstein cows fed oleamide or canola oil. J. Dairy Sci. 81:794-800.

Jenkins, T. C., V. Fellner, and R. K. McGuffey. 2003. Monensin by fat interactions on trans fatty acids in cultures of mixed ruminal microorganisms grown in continuous fermentors fed corn or barley. J. Dairy Sci. 86:324-330.

Kadegowda, A. K. G., L. S. Piperova, and R. A. Erdman. 2008. Principal component and multivariate analysis of milk long-chain fatty acid composition during diet-induced milk fat depression. J. Dairy Sci. 91:749-759.

Kalscheur, K. F., B. B. Teter, L. S. Piperova, and R. A. Erdman. 1997. Effect of fat source on duodenal flow of trans-C18:1 fatty acids and milk fat production in dairy cows. J. Dairy Sci. 80:2115-2126.

Lean, I. J., M. Curtis, R. Dyson, and B. Lowe. 1994. Effects of sodium monensin on reproductive performance of dairy cattle. I. Effects on conception rates, calving-to-conception intervals, calving-to-heat and milk production in dairy cows. Aust. Vet. J. 71:273-277.

Leonardi, C., S. Bertics, and L. E. Armentano. 2005. Effect of increasing oil from distillers grains or corn oil on lactation performance. J. Dairy Sci. 88:2820-2827.

Lock, A. L., T. R. Overton, K. J. Harvatine, J. G. Giesy, and D. E. Bauman. 2006. Milk fat depression: Impact of dietary components and their interaction during rumen fermentation. Pages 75-85 in Proc. Cornell Nutr. Conf. Dept. of Anim. Sci., Cornell University, Syracuse, NY

Lock, A. L., C. Tyburczy, D. A. Dwyer, K. J. Harvatine, F. Destaillats, Z. Mouloungui, L. Candy, and D. E. Bauman. 2007. Trans-10 octadecenoic acid does not reduce milk fat synthesis in dairy cows. J. Nutr. 137:71-76.

Loor, J. J., A. Ferlay, A. Ollier, K. Ueda, M. Doreau, and Y. Chilliard 2005. High-concentrate diets and polyunsaturated oils alter trans and conjugated isomers in bovine rumen, blood, and milk. J. Dairy Sci. 88:3986-3999.

NRC. 2001. Nutrient Requirements of Dairy Cattle. 7th rev. ed. Natl. Acad. Sci., Washington, DC.

Odongo, N. E., R. Bagg, G. Vessie, P. Dick, M. M. Or-Rashid, S. E. Hook, J. T. Gray, E. Kebreab, J. France, and B. W. McBride. 2007. Long-term effects of feeding monensin on methane production in lactating dairy cows. J. Dairy Sci. 90:1781-1788.

Perfield, J. W., II, A. L. Lock, J. M. Griinari, A. Sæbø, P. Delmonte, D. A. Dwyer, and D. E. Bauman. 2007. Trans-9, cis-11 conjugated 
linoleic acid reduces milk fat synthesis in lactating dairy cows. J. Dairy Sci. 90:2211-2218.

Phipps, R. H., J. I. D. Wilkinson, L. J. Jonker, M. Tarrant, A. K. Jones, and A. Hodge. 2000. Effect of monensin on milk production of Holstein-Friesian dairy cows. J. Dairy Sci. 83:2789-2794.

Rego, O. A., S. P. Alves, L. M. S. Antunes, H. J. D. Rosa, C. F. M. Alfaia, J. A. M. Prates, A. R. J. Cabrita, A. J. M. Fonseca, and R. J. B. Bessa. 2009. Rumen biohydrogenation-derived fatty acids in milk fat from grazing dairy cows supplemented with rapeseed, sunflower, or linseed oils. J. Dairy Sci. 92:4530-4540.

Sæbø, A., P.-C. Sæbø, J. M. Griinari, and K. J. Shingfield. 2005. Effect of abomasal infusion of geometric isomers of 10,12 conjugated linoleic acid on milk fat synthesis in dairy cows. Lipids 40:823-832.

Sauer, F. D., V. Fellner, R. Kinsman, J. K. Kramer, H. A. Jackson, A. J. Lee, and S. Chen. 1998. Methane output and lactation response in Holstein cattle with monensin or unsaturated fat added to the diet. J. Anim. Sci. 76:906-914.
Selner, D. R., and L. H. Schultz. 1980. Effects of feeding oleic acid or hydrogenated vegetable oils to lactating cows. J. Dairy Sci. 63:1235-1241.

Shaw, J. C., and W. L. Ensor. 1959. Effect of feeding cod liver oil and unsaturated fatty acids on rumen volatile fatty acids and milk fat content. J. Dairy Sci. 42:1238-1240.

Shingfield, K. J., A. Sæbø, P.-C. Sæbø, V. Toivonen, and J. M. Griinari. 2009. Effect of abomasal infusions of a mixture of octadecenoic acids on milk fat synthesis in lactating cows. J. Dairy Sci. 92:4317-4329.

Sukhija, P. S., and D. L. Palmquist. 1988. Rapid method for determination of total fatty acid content and composition in feedstuffs and feces. J. Agric. Food Chem. 36:1202-1206.

Tyrrell, H. F., and J. T. Reid. 1965. Prediction of the energy value of cow's milk. J. Dairy Sci. 48:1215-1223. 